\title{
Geologic Framework for the National Assessment of Carbon Dioxide Storage Resources-Atlantic Coastal Plain and Eastern Mesozoic Rift Basins
}

By William H. Craddock, Matthew D. Merrill, Tina L. Roberts-Ashby, Sean T. Brennan, Marc L. Buursink, Ronald M. Drake II, Peter D. Warwick, Steven M. Cahan, Christina A. DeVera, Phillip A. Freeman, Mayur A. Gosai, and Celeste D. Lohr

Chapter $\mathrm{N}$ of

Geologic Framework for the National Assessment of Carbon Dioxide Storage Resources Edited by Peter D. Warwick and Margo D. Corum

Open-File Report 2012-1024-N 


\title{
U.S. Department of the Interior RYAN K. ZINKE, Secretary
}

\author{
U.S. Geological Survey \\ James F. Reilly II, Director
}

\section{U.S. Geological Survey, Reston, Virginia: 2018}

For more information on the USGS - the Federal source for science about the Earth, its natural and living resources, natural hazards, and the environment-visit https://www.usgs.gov or call 1-888-ASK-USGS (1-888-275-8747).

For an overview of USGS information products, including maps, imagery, and publications, visit https://store.usgs.gov.

Any use of trade, firm, or product names is for descriptive purposes only and does not imply endorsement by the U.S. Government.

Although this information product, for the most part, is in the public domain, it also may contain copyrighted materials as noted in the text. Permission to reproduce copyrighted items must be secured from the copyright owner.

Suggested citation:

Craddock, W.H., Merrill, M.D., Roberts-Ashby, T.L., Brennan, S.T., Buursink, M.L., Drake, R.M., II, Warwick, P.D., Cahan, S.M., DeVera, C.A., Freeman, P.A., Gosai, M.A., and Lohr, C.D., 2018, Geologic framework for the national assessment of carbon dioxide storage resources-Atlantic Coastal Plain and Eastern Mesozoic Rift Basins, chap. N of Warwick, P.D., and Corum, M.D., eds., Geologic framework for the national assessment of carbon dioxide storage resources: U.S. Geological Survey Open-File Report 2012-1024-N, 32 p., https://doi.org/10.3133/ofr20121024N. 


\section{Editors' Preface}

\section{By Peter D. Warwick and Margo D. Corum}

The 2007 Energy Independence and Security Act (Public Law 110-140; U.S. Congress, 2007) directs the U.S. Geological Survey (USGS) to conduct a national assessment of potential geologic storage resources for carbon dioxide $\left(\mathrm{CO}_{2}\right)$ and to consult with other Federal and State agencies to locate the pertinent geological data needed for the assessment. The geologic storage of $\mathrm{CO}_{2}$ is one possible way to mitigate its effects on climate change.

The methodology used by the USGS for the assessment was described by Brennan and others (2010), who revised the methodology by Burruss and others (2009) according to comments from peer reviewers, an external panel of experts, and members of the public. During the implementation phase of the assessment (from 2010 to 2012), several practical steps were added to the assessment methodology of Brennan and others (2010). The details of the methodology used in the assessment are described in Blondes and others (2013). The assessment methodology is non-economic and is intended to be used at regional to sub-basinal scales.

The operational unit of the assessment is a storage assessment unit (SAU), which is composed of a porous storage formation with fluid flow and an overlying fine-grained sealing unit. Assessments are conducted at the SAU level and are aggregated to basinal and regional results. SAUs have a minimum depth of 3,000 feet ( $\mathrm{ft}$ ), which ensures that the $\mathrm{CO}_{2}$ is in a supercritical state, and thus occupies less pore space than a gas. Standard SAUs have a maximum depth of 13,000 ft below the surface, a depth accessible with average injection pipeline pressures (Burruss and others, 2009; Brennan and others, 2010; Blondes and others, 2013). Where geologic conditions favor $\mathrm{CO}_{2}$ storage below $13,000 \mathrm{ft}$, an additional deep SAU is assessed.

The assessments are also constrained by the occurrence of relatively fresh formation water; any formation water having a salinity less than 10,000 parts per million (ppm, which is equivalent to milligrams per liter, $\mathrm{mg} / \mathrm{L}$ ) total dissolved solids (TDS), regardless of depth, has the potential to be used as a potable water supply (U.S. Environmental Protection Agency, 2009). The U.S. Environmental Protection Agency (EPA) (2010) defines the lower limit of 10,000 ppm (mg/L) TDS for injection of $\mathrm{CO}_{2}$. Therefore, the potential storage resources for $\mathrm{CO}^{2}$ in formations where formation waters have salinities less than $10,000 \mathrm{ppm}(\mathrm{mg} / \mathrm{L})$ TDS are not assessed (Brennan and others, 2010; Blondes and others, 2013).

This report series contains a geologic description of each SAU identified within each report's assessed basins and focuses on particular characteristics specified in the methodology that influence the potential $\mathrm{CO}_{2}$ storage resource. The geologic framework information contained in these reports was used to calculate a statistical Monte Carlo-based distribution of potential storage space in the various SAUs following Brennan and others (2010) and Blondes and others (2013). Assessment data, results, and summary can be found in the U.S. Geological Survey Geologic Carbon Dioxide Storage Resources Assessment Team's $(2013 a, b, c)$ reports. Figures in this report series show SAU boundaries and cell maps of well penetrations through the sealing unit into the top of the storage formation. Wells sharing the same well borehole are treated as a single penetration. Cell maps show the number of penetrating wells within one square mile and are derived from interpretations of incompletely attributed well data (IHS Energy Group, 2011; and other data as available), a digital compilation that is known not to include all drilling. The USGS does not expect to know the location of all wells and cannot guarantee the amount of drilling through specific formations in any given cell shown on cell maps. 


\section{References Cited}

Blondes, M.S., Brennan, S.T., Merrill, M.D., Buursink, M.L., Warwick, P.D., Cahan, S.M., Cook, T.A., Corum, M.D., Craddock, W.H., DeVera, C.A., Drake, R.M., II, Drew, L.J., Freeman, P.A., Lohr, C.D., Olea, R.A., Roberts-Ashby, T.L., Slucher, E.R., and Varela, B.A., 2013, National assessment of geologic carbon dioxide storage resources-Methodology implementation: U.S. Geological Survey Open-File Report 2013-1055, 26 p., http://pubs.usgs.gov/of/2013/1055/.

Brennan, S.T., Burruss, R.C., Merrill, M.D., Freeman, P.A., and Ruppert, L.F., 2010, A probabilistic assessment methodology for the evaluation of geologic carbon dioxide storage: U.S. Geological Survey Open-File Report 2010-1127, 31 p., accessed March 22, 2011, at http://pubs.usgs.gov/of/2010/1127/.

Burruss, R.C., Brennan, S.T., Freeman, P.A., Merrill, M.D., Ruppert, L.F., Becker, M.F., Herkelrath, W.N., Kharaka, Y.K., Neuzil, C.E., Swanson, S.M., Cook, T.A., Klett, T.R., Nelson, P.H., and Schenk, C.J., 2009, Development of a probabilistic assessment methodology for evaluation of carbon dioxide storage: U.S. Geological Survey Open-File Report 2009-1035, 81 p., accessed March 22, 2011, at http://pubs.usgs.gov/of/2009/1035/.

IHS Energy Group, 2011, ENERDEQ U.S. well data: IHS Energy Group, online database available from IHS Energy Group, 15 Inverness Way East, D205, Englewood, CO 80112, U.S.A., accessed January 20, 2011.

U.S. Congress, 2007, Energy Independence and Security Act of 2007-Public Law 110-140: U.S. Government Printing Office, 311 p., accessed October 30, 2012, at http://frwebgate.access.gpo.gov/cgi-bin/getdoc.cgi?dbname=110_cong_ public_laws\&docid=f:publ140.110.pdf.

U.S. Environmental Protection Agency, 2009, Safe Drinking Water Act (SDWA): Washington, D.C., U.S. Environmental Protection Agency website, accessed January 14, 2009, at http://www.epa.gov/ogwdw/sdwa/index.html.

U.S. Environmental Protection Agency, 2010, Final rule for Federal requirements under the underground injection control (UIC) program for carbon dioxide $\left(\mathrm{CO}_{2}\right)$ geologic sequestration (GS) wells: Washington, D.C., U.S. Environmental Protection Agency website, accessed October 15, 2012, at http://water.epa.gov/type/groundwater/uic/class6/gsregulations.cfm.

U.S. Geological Survey Geologic Carbon Dioxide Storage Resources Assessment Team, 2013a, National assessment of geologic carbon dioxide storage resources—Summary (ver. 1.1, September 2013): U.S. Geological Survey Fact Sheet 2013-3020, 6 p., http://pubs.usgs.gov/fs/2013/3020/. [Supersedes ver. 1.0 released June 26, 2013.]

U.S. Geological Survey Geologic Carbon Dioxide Storage Resources Assessment Team, 2013b, National assessment of geologic carbon dioxide storage resources—Data (ver. 1.1, September 2013): U.S. Geological Survey Data Series 774, 13 p., plus 2 appendixes and 2 large tables in separate files, http://pubs.usgs.gov/ds/774/. [Supersedes ver. 1.0 released June 26, 2013.]

U.S. Geological Survey Geologic Carbon Dioxide Storage Resources Assessment Team, 2013c, National assessment of geologic carbon dioxide storage resources—Results (ver. 1.1, September 2013): U.S. Geological Survey Circular 1386, 41 p., http://pubs.usgs.gov/circ/1386/. [Supersedes ver. 1.0 released June 26, 2013.] 


\section{Contents}

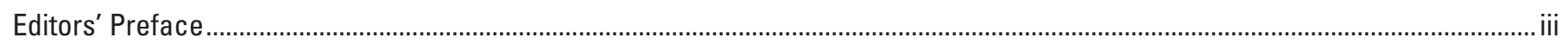

Abstract

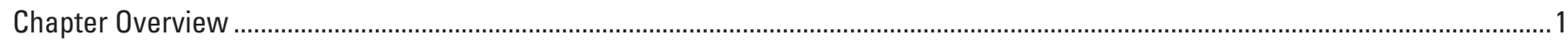

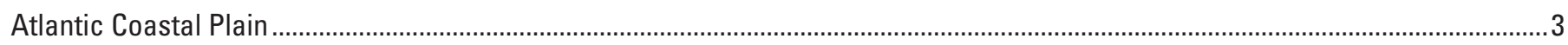

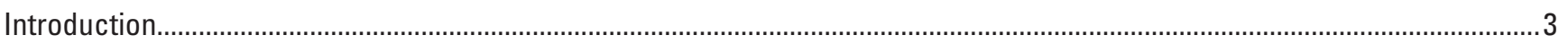

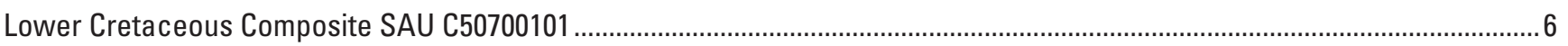

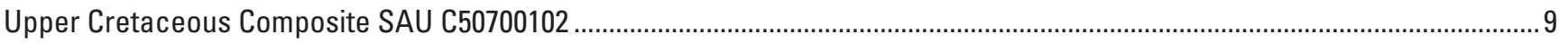

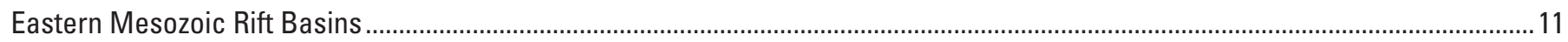

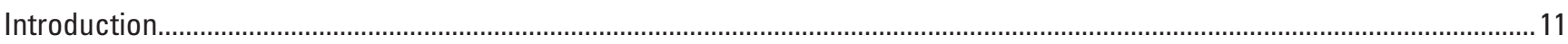

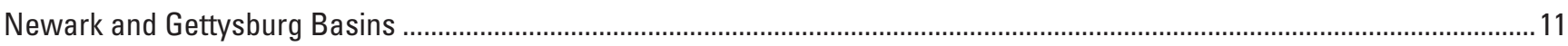

Stockton Formation SAU C50680101 and New Oxford Formation SAU C50680201 …...............................................................15

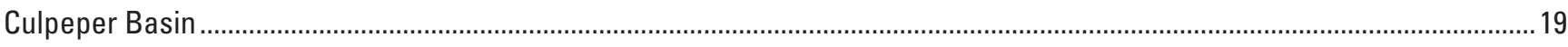

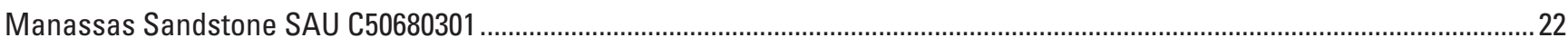

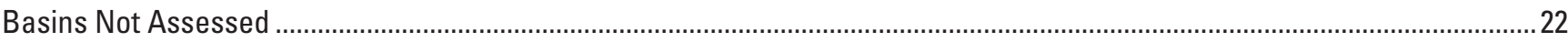

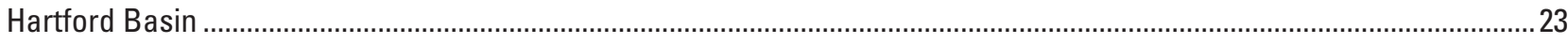

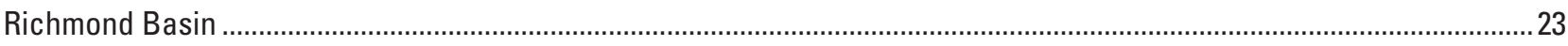

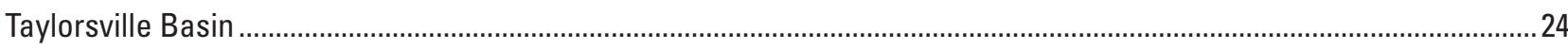

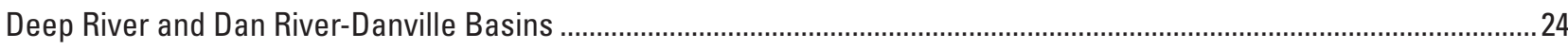

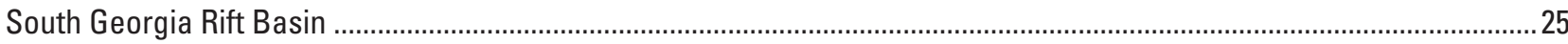

Acknowledgments

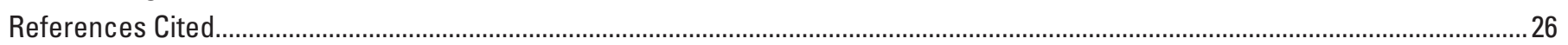

\section{Figures}

1. Map showing study areas in the Eastern United States that were examined for geologic carbon dioxide

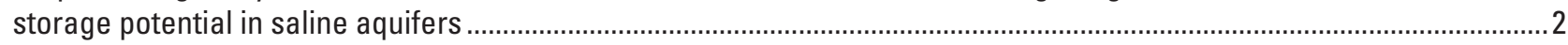

2. Stratigraphic column for the Pamlico embayment and the Southeast Georgia embayment ..............................................5

3. Map showing the area underlain by the Lower Cretaceous Composite Storage Assessment Unit (SAU) in the Atlantic Coastal Plain study area ...............................................................................................................................

4. Map showing the area underlain by the Upper Cretaceous Composite Storage Assessment Unit (SAU) in the

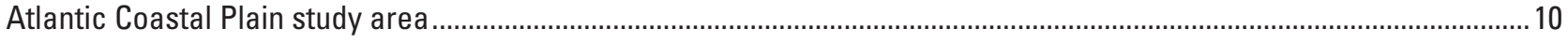

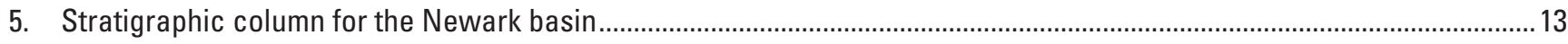

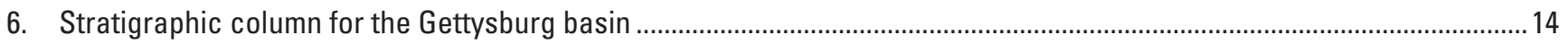

7. Map showing the area underlain by the Stockton Formation Storage Assessment Unit (SAU) in the Eastern

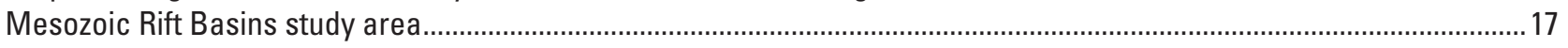

8. Map showing the area underlain by the New Oxford Formation Storage Assessment Unit (SAU) in the Eastern

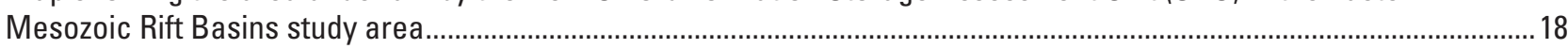

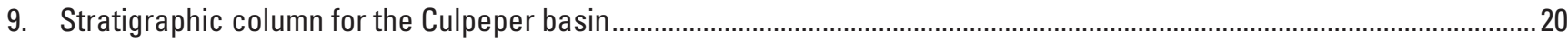

10. Map showing the Culpeper basin and the area underlain by the Manassas Sandstone Storage Assessment Unit (SAU) in the Eastern Mesozoic Rift Basins study area. 


\section{Conversion Factors}

\begin{tabular}{|c|c|c|}
\hline Multiply & By & To obtain \\
\hline \multicolumn{3}{|c|}{ Length } \\
\hline foot (ft) & 0.3048 & meter $(\mathrm{m})$ \\
\hline mile (mi) & 1.609 & kilometer (km) \\
\hline \multicolumn{3}{|c|}{ Area } \\
\hline acre & 0.4047 & hectare (ha) \\
\hline acre & 0.004047 & square kilometer $\left(\mathrm{km}^{2}\right)$ \\
\hline square mile $\left(\mathrm{mi}^{2}\right)$ & 2.590 & square kilometer $\left(\mathrm{km}^{2}\right)$ \\
\hline \multicolumn{3}{|c|}{ Volume } \\
\hline barrel (bbl; petroleum, 1 barrel=42 gal) & 0.1590 & cubic meter $\left(\mathrm{m}^{3}\right)$ \\
\hline gallon (gal) & 3.785 & liter (L) \\
\hline cubic foot $\left(\mathrm{ft}^{3}\right)$ & 0.02832 & cubic meter $\left(\mathrm{m}^{3}\right)$ \\
\hline
\end{tabular}

\section{Abbreviations}

$\mathrm{CO}_{2}$ carbon dioxide

D darcy, darcies

EPA U.S. Environmental Protection Agency

$\mathrm{ft}$ foot

$\mathrm{mD}$ millidarcy, millidarcies

mi mile

ppm part per million

SAU storage assessment unit

TDS total dissolved solids

USGS U.S. Geological Survey 


\title{
Geologic Framework for the National Assessment of Carbon Dioxide Storage Resources-Atlantic Coastal Plain and Eastern Mesozoic Rift Basins
}

\author{
By William H. Craddock, Matthew D. Merrill, Tina L. Roberts-Ashby, Sean T. Brennan, Marc L. Buursink, \\ Ronald M. Drake II, Peter D. Warwick, Steven M. Cahan, Christina A. DeVera, Phillip A. Freeman, \\ Mayur A. Gosai, and Celeste D. Lohr
}

\section{Abstract}

This chapter presents information pertinent to the geologic carbon dioxide $\left(\mathrm{CO}_{2}\right)$ sequestration potential within saline aquifers located in the Atlantic Coastal Plain and Eastern Mesozoic Rift Basins of the Eastern United States. The Atlantic Coastal Plain is underlain by a Jurassic to Quaternary succession of sedimentary strata that onlap westward onto strata of the Appalachian Piedmont physiographic province and generally thicken eastward toward the present-day Atlantic coastline and onto the present-day continental shelf. Although no significant petroleum discoveries have been made on the coastal plain, the deep saline aquifers of the region appear to contain porous strata (potential reservoirs, or "storage formations") that are overlain by fine-grained, laterally continuous strata (potential seals), which are prospective $\mathrm{CO}_{2}$ sequestration targets. For the Atlantic Coastal Plain, we identify two storage assessment units (SAUs), both of which consist of Cretaceous strata. The two SAUs are the Lower Cretaceous Composite SAU C50700101 and the Upper Cretaceous Composite SAU C50700102.

The Eastern Mesozoic Rift Basins are a chain of generally southwest- to northeast-trending, elongate sedimentary basins that either underlie the Atlantic Coastal Plain or crop out within adjacent geologic provinces to the west. Similar to the Atlantic Coastal Plain, there has been no significant oil and gas production from any of the basins, although there is a proven petroleum system in several of them. At least three of these basins appear to contain potential storage formations overlain by potential seal units. Most of the other basins were not assessed because a storage and (or) seal formation could not be established in the timeframe of the assessment, often because of the paucity of subsurface data for these basins in comparison to other petroliferous basins of the United States. Thus, we present information supporting one quantitative assessment in the Newark basin, as well as information supporting two nonquantitative assessments, one for strata in the Gettysburg basin and the other for strata in the Culpeper basin. We briefly discuss six other basins within the Eastern Mesozoic Rift Basins that were not assessed.

For all SAUs, we discuss the areal distribution of suitable $\mathrm{CO}_{2}$ reservoir rock. We also describe the overlying sealing unit and the geologic characteristics that influence the potential $\mathrm{CO}_{2}$ storage volume and reservoir characteristics. These characteristics include storage formation depth, gross thickness, net thickness, porosity, permeability, and groundwater salinity. Case-by-case strategies for estimating the pore volume existing within structurally and (or) stratigraphically closed traps are presented. Although assessment results are not contained in this chapter, the geologic information included herein was used to calculate the potential storage space in the SAUs.

\section{Chapter Overview}

This chapter begins with a brief review of the regional geology of the Atlantic Coastal Plain of the Eastern United States (see outline on fig. 1). Following this introductory material, we present geologic information that was used to assess the carbon dioxide $\left(\mathrm{CO}_{2}\right)$ storage potential of two stratigraphic units that are saline aquifers. The results of the quantitative assessments were presented by the U.S. Geological Survey Geologic Carbon Dioxide Storage Resources Assessment Team (2013a,b,c). Next, we present a brief review of the regional geology of the Mesozoic rift basins of the Eastern United States (see outlines on fig. 1). This review is followed by a presentation of the information that was used to quantitatively assess the $\mathrm{CO}_{2}$ storage potential of one geologic unit in the Newark basin and to nonquantitatively assess the $\mathrm{CO}_{2}$ storage potential of two geologic units within the Gettysburg and Culpeper basins, respectively (also see U.S. Geological Survey Geologic Carbon Dioxide Storage Resources Assessment Team, 2013a,b,c). The chapter closes with a brief discussion of six rift basins that do not appear to contain strata that are suitable for geologic CO2 sequestration within saline aquifers according to the criteria outlined by Blondes and others (2013). 


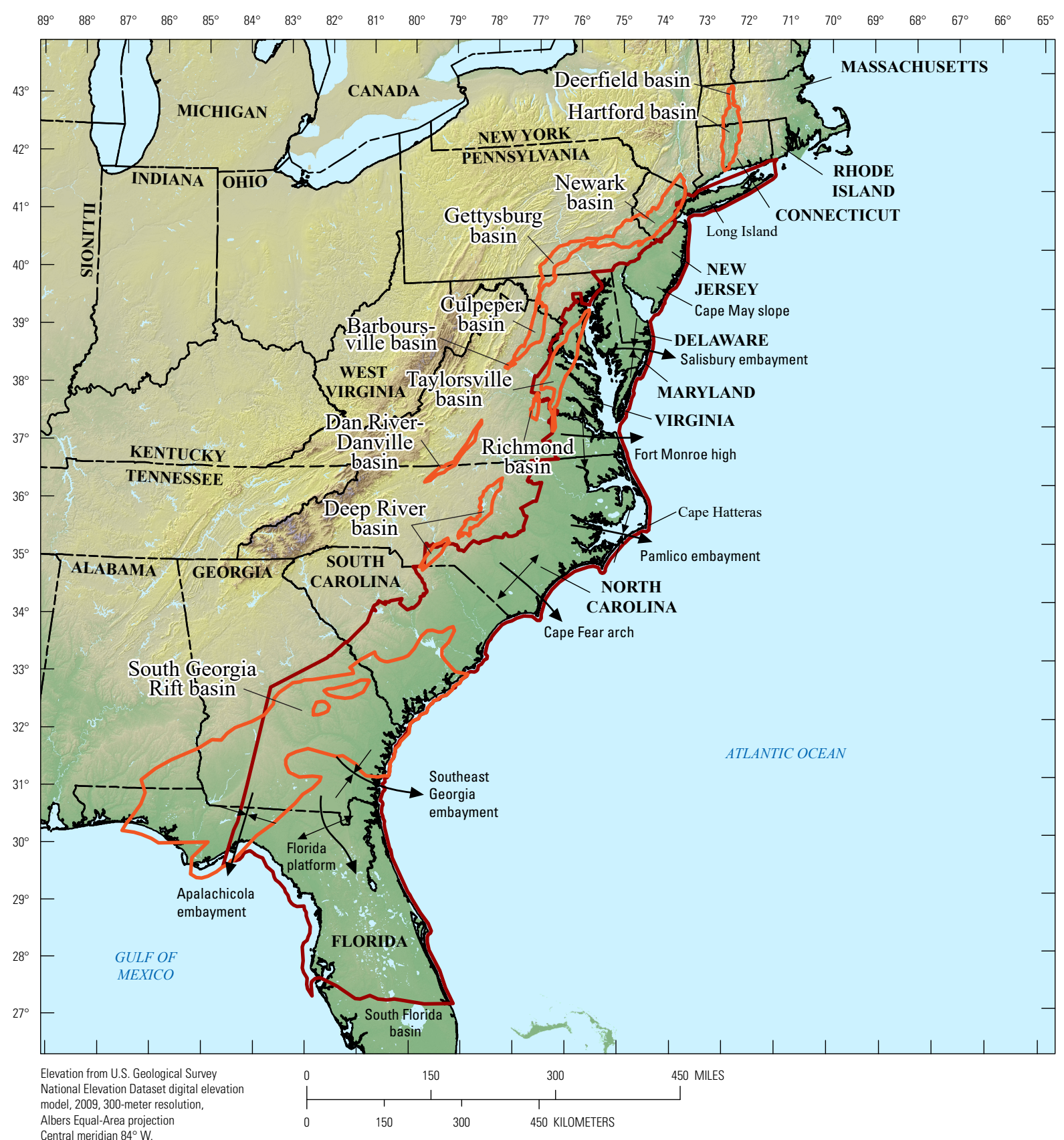

Central meridian $84^{\circ} \mathrm{W}$

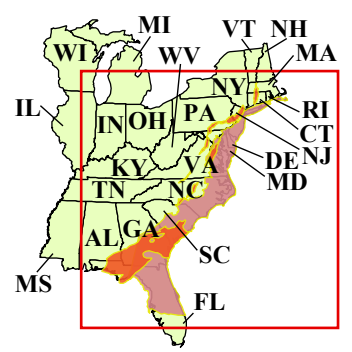

EXPLANATION

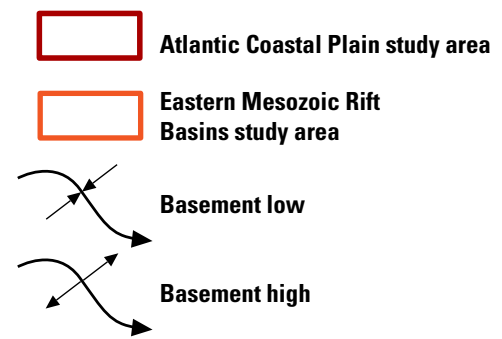

Figure 1. Map showing study areas in the Eastern United States that were examined for geologic carbon dioxide storage potential in saline aquifers. These areas include the onshore and State waters Eastern Mesozoic Rift Basins along the eastern continental margin and the overlying, onshore and State waters, Mesozoic through Cenozoic passive continental margin strata of the Atlantic Coastal Plain. The study areas are based on sedimentary basin boundaries adapted from Coleman and Cahan (2012, fig. 2). Major structural elements are adapted from Richards (1945) and Barnett (1975). 


\title{
Atlantic Coastal Plain
}

\author{
By William H. Craddock, Tina L. Roberts-Ashby, Steven M. Cahan, Christina A. DeVera, Phillip A. Freeman, \\ Mayur A. Gosai, and Celeste D. Lohr
}

\section{Introduction}

The Atlantic Coastal Plain is underlain by a Middle Jurassic to Quaternary succession of passive continental margin strata. The onshore strata that underlie the Atlantic Coastal Plain are the focus of this study and extend from south-central Florida northeastward to Long Island, New York (fig. 1) (Richards, 1945, 1967). We informally define the boundary between the U.S. Gulf of Mexico and the Atlantic Coastal Plain as the axis of the Apalachicola embayment, an approximately southsouthwest-plunging structural low in southwestern Georgia and adjacent areas in Florida (fig. 1). To the north, the western boundary of the Atlantic Coastal Plain is marked by the onlapping or pinching out of the passive-margin strata along the rocks of the Piedmont physiographic province. This boundary is called the Fall Line. East of the Fall Line, the Atlantic Coastal Plain stratigraphic succession thickens progressively to the east.

The onshore portion of the continental margin includes several distinct basement lows (embayments) and basement highs (fig. 1). The northernmost embayment is the Salisbury embayment of southeastern Maryland and Delaware. On the northern side of the Salisbury embayment, a south-dipping basement surface (the Cape May slope) extends to a relatively structurally high area in Long Island, New York. To the east of Long Island, the Fall Line merges with the coastline, defining the northeastern limit of the area reviewed in this chapter. On the southern side of the Salisbury embayment, the basement dips at a low angle to the north and extends to the Fort Monroe high in southeastern Virginia (Richards, 1945, 1967). South of the Fort Monroe high is the Pamlico embayment of central-eastern North Carolina. In the vicinity of Cape Hatteras, North Carolina, the Pamlico embayment exhibits the thickest succession of strata anywhere along the onshore portion of the continental margin (Maher, 1971). The Pamlico embayment is bordered to the south by the Cape Fear arch of southeastern North Carolina. Basement rocks deepen to the south of the Cape Fear arch, defining the Southeast Georgia embayment (also referred to as the Beaufort basin by Richards, 1945, 1967), which is the southernmost Atlantic-facing embayment in our study area. We informally define the southern boundary of the Southeast Georgia embayment as the Florida platform or the peninsular arch, a broad basement high in northern Florida (Applin and Applin, 1965; Barnett, 1975), and use it to distinguish Atlantic Coastal Plain strata from those deposited in the South Florida basin, which is underlain by a basement low to the south of the Florida platform (fig. 1) (Applin and Applin, 1965).

Strata of the Atlantic Coastal Plain were deposited following the breakup of the Pangea continent, which commenced along the Atlantic continental margin during the Triassic Period. During the rifting that occurred between the Late Triassic and the Early Jurassic Periods, a chain of basins developed along the continental margin in the footwalls of major normal faults. Sea-floor spreading and the generation of oceanic crust adjacent to the Atlantic continental margin began in the Middle Jurassic, marking the end of rift-related tectonism. The passive-margin strata of the Atlantic Coastal Plain, which are the focus of this chapter, accumulated from the Middle Jurassic to the present and covered many of the Triassic-Jurassic strata in the rift-related basins (Miall and others, 2008). One of the primary controls on the distribution and character of the passive-margin strata of the Atlantic Coastal Plain was eustatic sea level. The regionally extensive accumulations of fine-grained material that were deposited during major transgressions are the stratigraphic intervals that we consider to be prospective regional seal units. Reviews by Maher (1971), Poag (1985), Sheridan and Grow (1988), and Miall and others (2008) contain additional information about the Mesozoic and Cenozoic geologic evolution of the Atlantic continental margin.

One indication that a basin may be well suited to geologic carbon dioxide $\left(\mathrm{CO}_{2}\right)$ sequestration in saline aquifers is historic oil and gas production from conventional reservoirs because this history implies the presence of three key elements of a petroleum system that are also critical to geologic $\mathrm{CO}_{2}$ sequestration: a reservoir, a trap, and a seal. Although there has been no petroleum production within the onshore Atlantic margin sediments of the Eastern United States, the Atlantic Coastal Plain nevertheless exhibits potential as a carbon sequestration site. Several regionally extensive, mappable saline aquifers are present in the deep subsurface. These aquifers are overlain by regionally extensive, fine-grained stratigraphic intervals that may serve as impermeable seals.

Two stratigraphic intervals within the Atlantic Coastal Plain meet the U.S. Geological Survey (USGS) criteria for assessing $\mathrm{CO}_{2}$ storage capacity in saline aquifers, and both are Cretaceous in age (fig. 2). The lower storage assessment unit (SAU) is a composite of the Lower Cretaceous strata (primarily Aptian and Albian) that is capped by a regionally extensive, finegrained Cenomanian stratigraphic interval (Brown and others, 1979; Almy, 1987). Because our assessment is restricted to strata that underlie more than 3,000 feet (ft) of overburden (Brennan and others, 2010; Blondes and others, 2013), the Lower 
Cretaceous section is sufficiently deep only within the Pamlico and Southeast Georgia embayments (fig. 1). The upper SAU is a composite of Upper Cretaceous strata that are capped by thick Campanian and Maastrichtian shale in the Pamlico embayment (Almy, 1987). The Upper Cretaceous section achieves depths sufficient for our purposes only in central North Carolina, within the Pamlico embayment. It is important to note that areas within the Salisbury embayment were excluded from the assessment because insufficient evidence for a regional seal could be compiled within the timeframe of the assessment. However, Cretaceous strata in Salisbury embayment have subsequently been characterized as a potential carbon sequestration target (Miller and others, 2017).

In the following sections, we characterize the distribution and stratigraphic character of each prospective SAU. We briefly summarize the key information that provides the basis for calculating the capacity of the SAUs for buoyant and residual $\mathrm{CO}_{2}$ storage (as described in Burruss and others, 2009; Brennan and others, 2010) as well as information that relates to the reservoir characteristics for each unit. Capacity is a function of SAU area, thickness, and porosity. The U.S. Environmental Protection Agency (EPA, 2009) stipulates that aquifers must contain groundwater that has a total dissolved solids (TDS) concentration of greater than 10,000 parts per million (ppm) to be used for $\mathrm{CO}_{2}$ storage; therefore, we characterize regional trends in groundwater quality, and only portions of reservoir intervals having TDS concentrations greater than 10,000 ppm are considered to be potential storage formations.

Finally, to differentiate between the pore volume contained within buoyant and residual traps (see Brennan and others, 2010; Blondes and others, 2013), we defined the pore volume enclosed within buoyant traps, which are analogous to stratigraphic and (or) structural hydrocarbon traps. Generally, for each SAU, the (1) minimum and (2) most likely pore volumes enclosed within buoyant traps were constrained on the basis of (1) the sum of the cumulative oil and gas production and the known hydrocarbon reserve volume and (2) the minimum buoyant volume plus the estimated volume of undiscovered resources (see Brennan and others, 2010; Blondes and others, 2013). Given that there is no historical oil or gas production from the SAUs presented in this chapter, we considered these numbers to be zero and we do not discuss them further. An upper bound for enclosed pore volume was also determined for each unit, and we describe our methods for this analysis on a case-by-case basis. The information derived from the data sources and methods described herein is used in accordance with the USGS carbon sequestration assessment methodology (Brennan and others, 2010; Blondes and others, 2013) to calculate the available storage capacity for $\mathrm{CO}_{2}$ within the SAUs. 


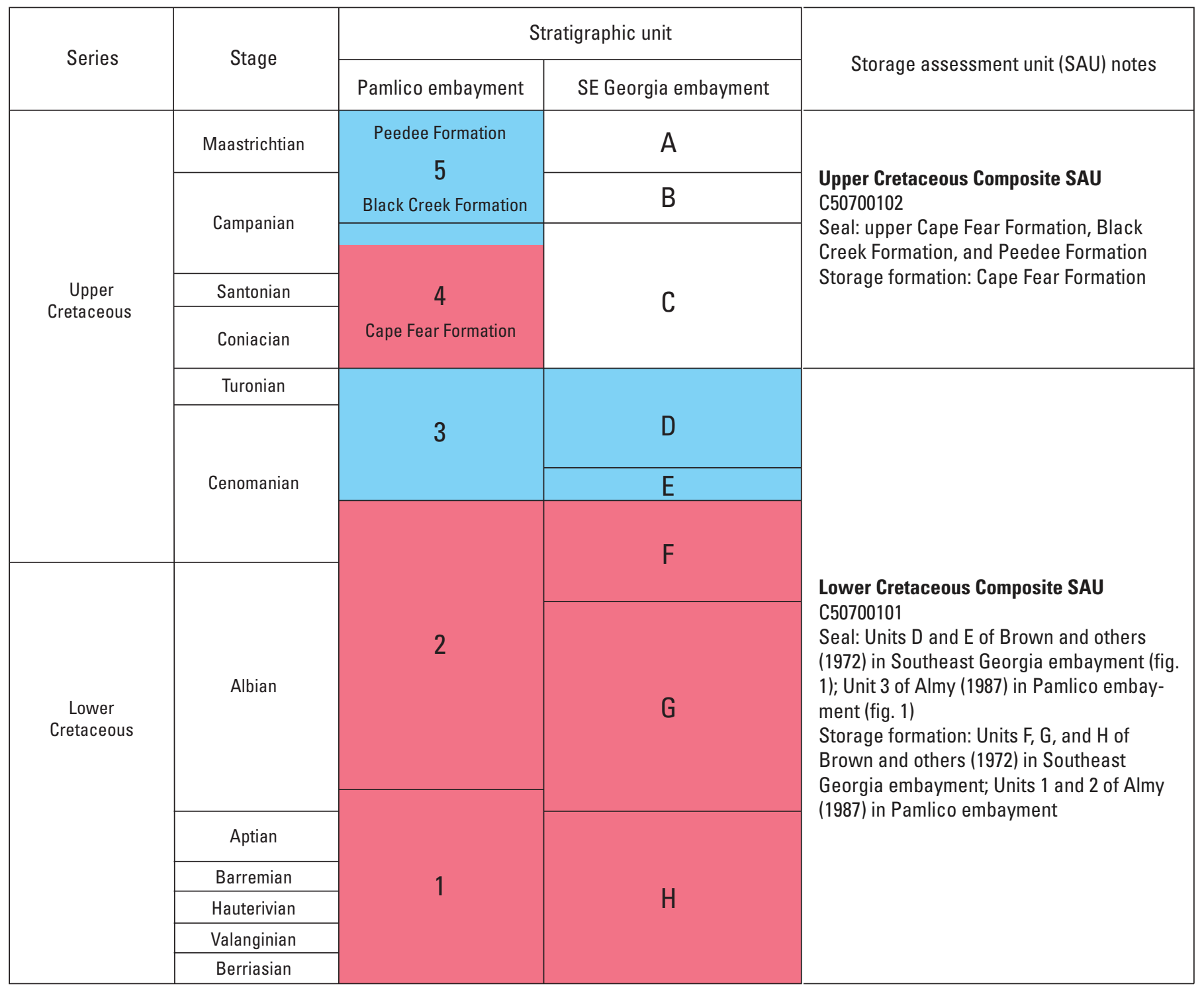

Figure 2. Stratigraphic column for the Pamlico embayment and the Southeast Georgia embayment. Storage assessment units consist of a storage formation (red) and regional seal (blue). Stratigraphic units are adapted from Almy (1987) and Winner and Coble (1996) for the Pamlico embayment and from Brown and others (1972) for the Southeast Georgia embayment. SE, southeast. 


\title{
Lower Cretaceous Composite SAU C50700101
}

\author{
By William H. Craddock
}

Thick accumulations of Lower Cretaceous strata were deposited in the Southeast Georgia embayment and the Pamlico embayment of North Carolina (fig. 1). The basal strata in the embayments are mostly Lower Cretaceous (Brown and others, 1979; Almy, 1987).

In the Southeast Georgia embayment, we use the stratigraphy and subsurface mapping of Brown and others (1972, 1979). As shown in figure 2 of this chapter, the potential storage formation corresponds primarily to unit F (Albian) in their work, although the reservoir also includes narrow swaths (in map view) of their units G and H (pre-Albian Lower Cretaceous) along the western edge of the SAU. The potential seal corresponds to the Cenomanian unit E and overlying Turonian unit D of Brown and others $(1972,1979)$.

In the Pamlico embayment, we use the stratigraphy and subsurface mapping of Almy (1987), which is based on the work of Brown and others $(1972,1979)$. As shown in figure 2 of this chapter, the storage formation corresponds to units 1 (Berriasian to lower Albian) and 2 (middle Albian to lower Cenomanian) of Almy (1987), and the seal unit corresponds to unit 3 (middle Cenomanian to Turonian) of Almy (1987).

Lithostratigraphic names for the units listed above vary by State and have evolved through time. For details about lithostratigraphic names, readers are referred to reports by Richards (1967), Poag (1978), and Renken (1996).

In the Southeast Georgia embayment, cores of Albian strata (unit F of Brown and others 1972, 1979) and geophysical logs from boreholes indicate that the strata typically consist of fine- to coarse-grained sandstone or loosely consolidated sand intercalated with mud and clay (Brown and others, 1979). Although sedimentologic and faunal evidence suggest that these strata were deposited in a variety of passive-margin depositional environments (Applin and Applin, 1965), most strata were deposited in shallow-marine environments (Applin and Applin, 1967). In the Pamlico embayment, an interpretation of well logs indicates that the Lower Cretaceous section consists of pre-Albian nonmarine sandstone, limestone, and shale (unit 1 of Almy, 1987) overlain by Albian and lower Cenomanian deltaic and prodeltaic sand and shale (unit 2 of Almy, 1987).

In both the Southeast Georgia and Pamlico embayments, Lower Cretaceous strata are overlain by what may be the thickest and most extensive fine-grained shale unit of the Atlantic Coastal Plain (units D and E of Brown and others, 1972, 1979, in Georgia; unit 3 of Almy, 1987, in North Carolina). The unit was deposited during a long-lived transgression and eustatic sea-level rise that began in the Cenomanian and persisted until the end of the Late Cretaceous (Miller and others, 2005). The fine-grained deposits appear to be significantly time-transgressive along the depositional dip: near the coastline, the youngest fine-grained units linked to this transgression typically date to the early or middle Cenomanian, whereas updip they may date to the Turonian or later (Brown and others, 1979). An inspection of well logs suggests that this Cenomanian shale is a laterally continuous, fairly homogeneous unit that is more than $100 \mathrm{ft}$ thick. Near the southern Georgia and northern Florida coastline, the unit is typically $100 \mathrm{ft}$ thick (Brown and others, 1979), whereas near the central North Carolina coastline, the unit is approximately $400 \mathrm{ft}$ thick (Almy, 1987). Given the thickness and stratigraphic character of this unit, it should constitute a robust upper seal on a regional basis. As mentioned above, although correlative Lower Cretaceous strata also occur at depths greater than 3,000 ft in the Salisbury embayment, this area was not assessed because a regional seal formation could not be ascertained within the timeframe of the assessment.

The boundaries of the Lower Cretaceous Composite SAU C50700101 are defined by the 3,000-ft depth to the top of the reservoir unit (see requirements discussed by Brennan and others, 2010) and State boundaries that extend 4 miles (mi) offshore of the Atlantic coastline (fig. 3). The maximum depth to the top of the storage formation is 5,200 ft. In both the Southeast Georgia and Pamlico embayments, the structural contours were adapted from existing maps showing contoured formation tops (Brown and others, 1979; Almy, 1987). The SAU underlies an area of about 14 million acres, and about 91 percent of the SAU area lies within the Southeast Georgia embayment.

The gross thickness of the Lower Cretaceous Composite SAU was compiled from isopach maps and differencing of structural contour maps presented in the reports by Brown and others (1979) and Almy (1987). Averaged across the entire SAU, the gross thickness of the storage formation is approximately $600 \mathrm{ft}$, but it ranges from a few hundred feet in Georgia to several thousand feet in North Carolina. To determine the net thickness of the porous strata within the reservoir interval, we interpreted the net sand thickness from gamma logs and spontaneous potential logs from 33 boreholes distributed across the SAU in the Southeast Georgia and Pamlico embayments (logs presented in Brown and others, 1979; Almy, 1987). Averaged across the SAU, the thickness of the porous reservoir rock in the storage formation ranges from 180 to $300 \mathrm{ft}$, although this range masks differences in the SAU between the two embayments. In the Southeast Georgia embayment, the net sandstone thickness is around $100 \mathrm{ft}$, whereas in the Pamlico embayment, the net sandstone thickness is around 1,500 ft. 
Information about the rock properties (porosity, permeability) of the Lower Cretaceous sandstones is sparse for the Atlantic Coastal Plain. Porosity measurements derived from geophysical logs from the storage formation in North Carolina suggest very high porosities, and the average across the region possibly approaches 35 percent (Reid and others, 2011). A few limited coreplug porosity measurements from the Lower Cretaceous rocks in North Carolina (depth around 7,000 ft) and Upper Cretaceous rocks in South Carolina (depth around 3,000 ft) suggest that regional porosities for Cretaceous strata mostly range between 20 and 35 percent (Spangler, 1950; Temples and Waddell, 1996). We supplemented the limited Atlantic Coastal Plain data with data from the similar Upper Cretaceous Tuscaloosa Group in the Gulf Coast. In the Gulf Coastal Plain, proprietary data indicate that the field-averaged porosity for petroleum-producing strata in the lower part of the Upper Cretaceous Tuscaloosa Group at depths between 3,000 and 6,000 ft is most likely about 25 percent (Nehring Associates, 2010). Because numerous measurements suggest that most Lower Cretaceous strata of the Atlantic Coastal Plain region are highly porous, we estimated that the average regional sand or sandstone porosity is approximately 32 percent.

Permeability measurements for Lower Cretaceous sand or sandstone are equally sparse in the Atlantic Coastal Plain. The aforementioned core plugs from North Carolina and South Carolina yield permeability measurements that range from a few millidarcies $(\mathrm{mD})$ to a few darcies (D). Proprietary data for petroleum-producing strata of the Tuscaloosa Group indicate that permeabilities may be as low as $0.1 \mathrm{mD}$, and we used this value as a lower bound on regional permeability (Nehring Associates, 2010). Given that measured permeabilities are often several darcies, we estimated that the most likely permeability for sand or sandstone in the region is 1.1 D and that an upper bound on permeability is 4.5 D (see Temples and Waddell, 1996; Nehring Associates, 2010).

Regional aquifer studies in the Southeast Georgia embayment indicate that the concentration of TDS in groundwater in Lower Cretaceous strata is high, typically between 10,000 and 100,000 ppm (Meisler, 1989; Winner and Coble, 1996). However, in the Southeast Georgia embayment, mapped contours representing TDS measurements within Lower Cretaceous aquifers suggest that the north-central part of the SAU may contain potable water (TDS $<10,000 \mathrm{ppm}$; EPA, 2009), whereas the southern part of the SAU contains saline waters that may be ideal for $\mathrm{CO}_{2}$ disposal and storage (Brown and others, 1979).

Given the lack of hydrocarbon production in the Atlantic Coastal Plain, it is difficult to estimate the pore volume that may be enclosed within structural and (or) stratigraphic traps, which is a quantity that can be constrained in petroliferous basins by petroleum production volumes. We defined the lower limit for pore volume as zero because we were not aware of any traps proven to retain buoyant fluids over geologic time. To place either the most likely or maximum constraints on enclosed pore volume in the Atlantic Coastal Plain, we assumed that the greatest potential for enclosure of pore volume is from stratigraphic closures on the relatively undeformed Cretaceous and Cenozoic continental margin. To constrain the likely size and net thickness of these stratigraphic traps, we again turned to the proprietary petroleum-production data from the Tuscaloosa Group of the Gulf Coastal Plain (Nehring Associates, 2010). For the analogous reservoirs, typical closure areas for large petroleum fields are approximately 2,500 acres. These enclosures typically involve a few tens of feet of sandy reservoir rock. On the basis of the density of stratigraphic traps identified for Upper Cretaceous strata in the Gulf Coastal Plain (Nehring Associates, 2010), we speculated that there are most likely 20 analogous stratigraphic traps distributed across this SAU, although there could be as many as 100 such analogous traps. By combining the closure area and net reservoir thickness with our regional constraints on porosity, we estimated the most likely and maximum enclosed pore volume (U.S. Geological Survey Geologic Carbon Dioxide Storage Resources Assessment Team, 2013b). 

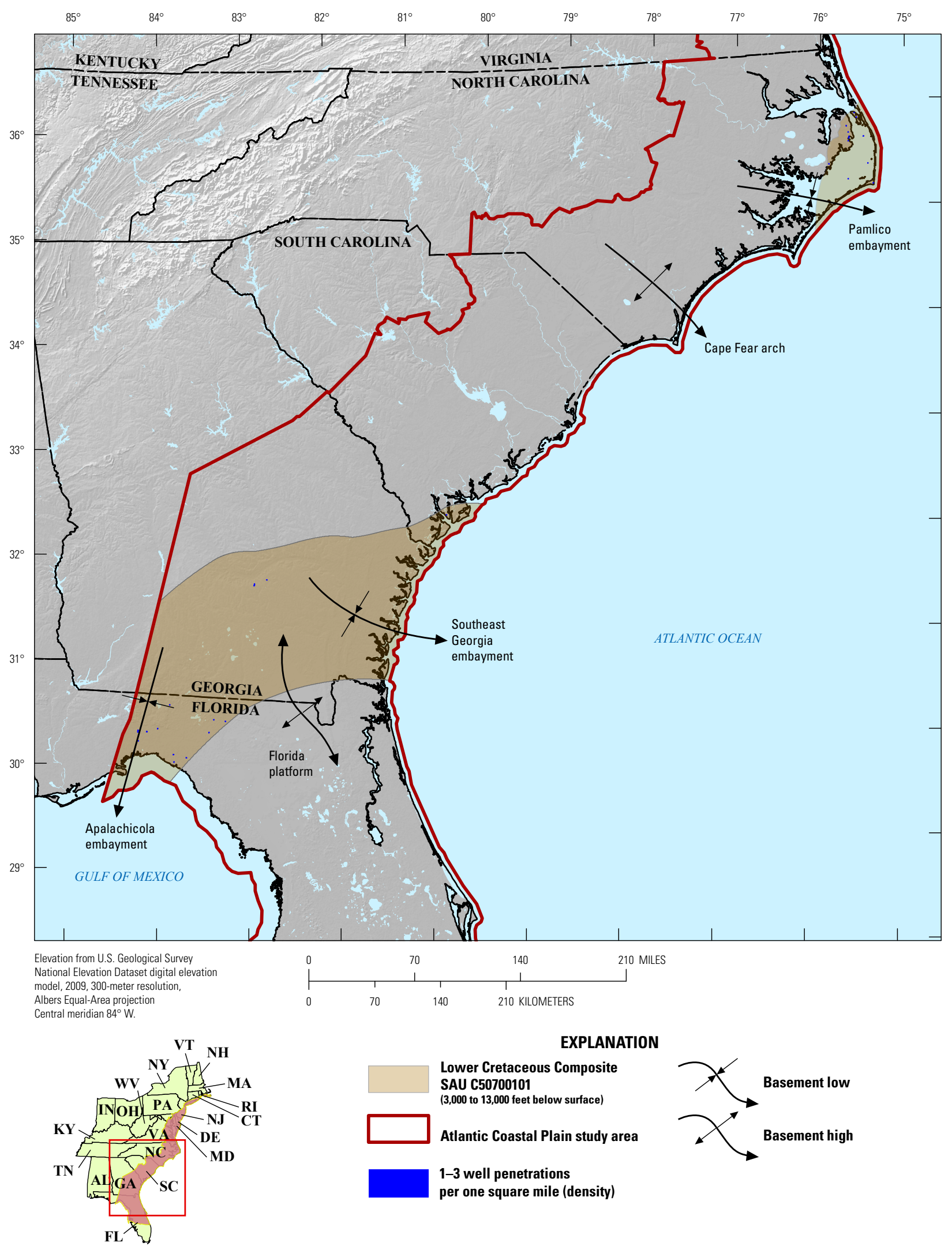

Figure 3. Map showing the area underlain by the Lower Cretaceous Composite Storage Assessment Unit (SAU) in the Atlantic Coastal Plain study area. Dark-blue grid cells (1 square mile) in the SAU display counts of wells derived from the IHS Energy Group (2011) well database that have penetrated the storage formation top. The Atlantic Coastal Plain study area is modified from Coleman and Cahan (2012, fig. 2). 


\title{
Upper Cretaceous Composite SAU C50700102
}

\author{
By Tina L. Roberts-Ashby
}

The Upper Cretaceous Cape Fear Formation forms a siliciclastic $\mathrm{CO}_{2}$ storage reservoir in the Atlantic Coastal Plain within an approximately 300,000-acre area near Cape Hatteras (figs. 2, 4). The Cape Fear Formation was deposited in a cyclic environment that resulted in interbedded marine and nonmarine sand, clay, and silt (Winner and Coble, 1996; Lautier, 2009). Two major permeable zones within the Cape Fear Formation form the regionally extensive upper and lower Cape Fear aquifers (Winner and Coble, 1996; Lautier, 2009), which collectively form the $\mathrm{CO}_{2}$ storage reservoir for the Upper Cretaceous Composite SAU C50700102. The sandy reservoir rocks are capped by an Upper Cretaceous composite seal that includes the clay-rich upper Cape Fear Formation confining unit together with the Black Creek and Peedee Formations. In the area of the SAU, sand of the Black Creek and Peedee Formations, units which form major aquifers in other areas of the Atlantic Coastal Plain, is largely replaced by shale, silt, and clay (Perry and others, 1975; Almy, 1987; Lautier, 2009), thereby creating a thick confining unit and seal.

The Upper Cretaceous Composite SAU C50700102 underlies an area of about 300,000 acres ( \pm 10 percent) (fig. 4). The depth to the top of the reservoir interval is between 3,000 and 4,000 ft. The boundary of the Upper Cretaceous Composite SAU is defined by the 3,000-ft depth to the top of the reservoir that was determined using the published cross sections of Almy (1987) and geophysical logs taken from several North Carolina oil and gas test wells (Reid and others, 2011). These same sources (Almy, 1987; Reid and others, 2011) were used to determine the gross thickness of the reservoir rocks within the SAU, which deepen and thicken seaward and range in thickness from 575 to $625 \mathrm{ft}$, and have a most likely thickness of $600 \mathrm{ft}$. Unlike the Lower Cretaceous Composite SAU, the Upper Cretaceous Composite SAU does not include any strata in either the Southeast Georgia or Salisbury embayments because the depths to the top of the storage formation are less than 3,000 $\mathrm{ft}$.

The average sand content of the upper and lower Cape Fear aquifers is 60 percent, although the sand content can be as great as 90 percent in some areas (Winner and Coble, 1996). Porosity and permeability data for the upper and lower Cape Fear aquifers are scarce in the area of the Upper Cretaceous Composite SAU. The average porosities in the porous sands were estimated using published log- and core-porosity values for the Upper Cretaceous rocks along strike to the south beneath coastal portions of South Carolina (Temples and Waddell, 1996); these porosities range from 28 to 34 percent and have a most likely value of 32 percent in the SAU depth range of about 3,000 to 5,000 ft. Test-well data from Temples and Waddell (1996) were also used to estimate the average permeabilities for the SAU, which range from 0.1 to $4,500 \mathrm{mD}$ and have a most likely value of $1,100 \mathrm{mD}$. The net sand thickness measurements taken from well geophysical logs located within the SAU were used to estimate the average net porous interval thicknesses, which range from 180 to $300 \mathrm{ft}$ throughout the study area and have a most likely value of $230 \mathrm{ft}$.

In the vicinity of Cape Hatteras where the SAU is located (fig. 4), the upper and lower Cape Fear aquifers are considered to be saline because the TDS exceeds the lower limit of $10,000 \mathrm{mg} / \mathrm{L}$ TDS designated by the EPA for saline aquifers (Winner and Coble, 1996; EPA, 2010). Therefore, 100 percent of the Upper Cretaceous Composite SAU is considered to be potentially suitable for sequestration of $\mathrm{CO}_{2}$. The storage volume within structurally enclosed traps was estimated following the methods for the Lower Cretaceous Composite Storage Assessment Unit, as described above (U.S. Geological Survey Geologic Carbon Dioxide Storage Resources Assessment Team, 2013b). 


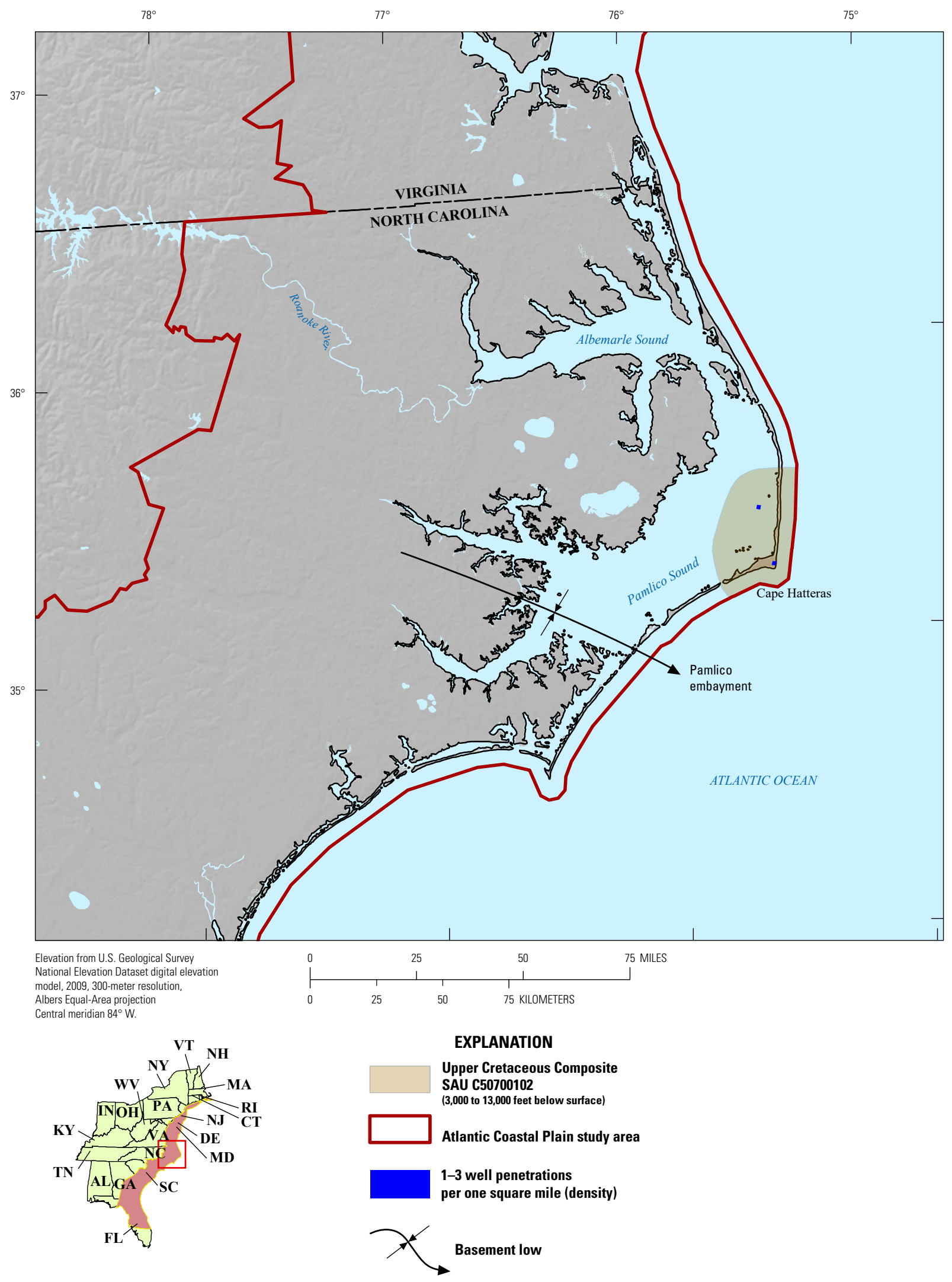

Figure 4. Map showing the area underlain by the Upper Cretaceous Composite Storage Assessment Unit (SAU) in the Atlantic Coastal Plain study area. Dark-blue grid cells (1 square mile) in the SAU display counts of wells derived from the IHS Energy Group (2011) well database that have penetrated the storage formation top. The Atlantic Coastal Plain study area is modified from Coleman and Cahan (2012, fig. 2). 


\title{
Eastern Mesozoic Rift Basins
}

\author{
By Matthew D. Merrill, Sean T. Brennan, Marc L. Buursink, Ronald M. Drake II, Peter D. Warwick, \\ Steven M. Cahan, Christina A. DeVera, Phillip A. Freeman, Mayur A. Gosai, and Celeste D. Lohr
}

\section{Introduction}

Late Triassic through Early Jurassic rifting of the Pangea continent and related sea-floor spreading produced 40 to 50 elongated rift basins along the eastern side of North America. The orientation of the basins follows the orientation of the late Paleozoic Alleghanian orogenic fabric (Manspeizer and others, 1989). These basins are referred to here as the Eastern Mesozoic Rift Basins, although other names are also in common use, such as "rift basins of the Central Atlantic Margins" (which include parallel basins in Morocco; Olsen, 1997) and "early Mesozoic basins of the Eastern United States" (Robinson and Froelich, 1985).

Two general types of basin structure and lithology resulted from the divergent tectonic activity beginning in the Late Triassic: (1) an onshore set of detrital rift basins and (2) a seaward shallow-margin or platform set of basins. With regard to the Eastern Mesozoic Rift Basins in this assessment, they are exclusively onshore (see fig. 1) and are, therefore, all detrital rift basins (Manspeizer and others, 1989). The basins are generally asymmetrical half-grabens bound by a dominant normal fault on either the eastern or western side and have strata dipping toward the fault. As described in the following basin-specific sections, strata in the basins are mostly siliciclastic strata that were deposited in fluvial and lacustrine settings. Basins from the Culpeper basin northward exhibit outcrops of igneous rocks in the form of lava flows, sills, and dikes. Igneous rocks, however, are reportedly present in the subsurface of basins to the south of the Culpeper basin (Daniels and others, 1983). Robinson and Froelich (1985), Manspeizer and others (1989), and Schlische (2003) provided thorough reviews of both the current state of knowledge and historical accounts of past hypotheses regarding the formation of these rift basins and the origin of their sedimentary and igneous components.

Nine onshore basins were chosen for investigation because of their potentially amenable geology for storage as well as the availability of geologic data (fig. 1). Roughly from north to south they are the Hartford, Newark, Gettysburg, Culpeper, Taylorsville, Richmond, Dan River-Danville, Deep River, and South Georgia Rift basins. Of those nine, three (Newark, Gettysburg, and Culpeper basins) were ultimately assessed with one storage assessment unit in each basin; of those, sufficient information to conduct a quantitative assessment could be gathered only for the Newark basin within the time frame of the assessment.

\section{Newark and Gettysburg Basins}

\section{By Sean T. Brennan}

The Newark basin trends northeast to southwest (fig. 1) and is bounded on the northwest by a complex of southeast-dipping faults (Schlische and Olsen, 1990) and on the southeast by unconformities on underlying metamorphic rocks (Smoot, 2010). The axis of the Newark basin is approximately $120 \mathrm{mi}$ long. Its present-day exposure is approximately 20 to $30 \mathrm{mi}$ wide, although much of the original extent apparently has been eroded (Schlische and Olsen, 1990). The basin is divided into four blocks by extensional faults; this results in the repetition of stratigraphic sections within the basin (Smoot, 2010). The basin has 23,000 ft of sedimentary fill, and the strata range in age from Late Triassic through Early Jurassic (Olsen and others, 1996; Smoot, 2010) (fig. 5).

The Gettysburg basin also trends northeast to southwest (fig. 1) and is bounded on the northwest by a border fault (Root, 1989), which has been interpreted as either a continuous fault (Cleaves and others, 1968; Berg, 1980) or a complex of discontinuous faults (Faill, 1973), and on the east by an unconformity between basin strata and the underlying metamorphic rocks (Lyttle and Epstein, 1987). The northern edge of the basin is known as the Narrow Neck (Root, 1989), which connects the Gettysburg basin with the Newark basin to the northeast and is present in Lancaster, Lebanon, and Bucks Counties in Pennsylvania (Luttrell, 1989). The axis of the Gettysburg basin is approximately $80 \mathrm{mi}$ long, and the basin has a maximum width of $22 \mathrm{mi}$ (Luttrell, 1989). The basin contains an estimated $21,000 \mathrm{ft}$ of sedimentary fill (Root, 1989), ranging in age from Late Triassic to Early Jurassic (fig. 6). 
Both the Newark and Gettysburg basins began to form because of the breakup of Pangea. The trend of the western borderfault complex for these basins mirrors the existing trend of the Appalachian front, indicating that the boundary faults may have resulted from the reactivation of existing faults or zones of pre-existing weakness (Schlische, 2003). The initial post-rift deposits within both basins were alluvial-fan deposits near the border faults and fluvial deposits farther from the border faults. The basal formation in the Newark basin is the Stockton Formation, which consists mainly of the following: (1) conglomerates and conglomeratic sandstone; (2) arkosic sandstone; and (3) micaceous sandstone, siltstone, and mudstone (Smoot, 2010). Within the Gettysburg basin, the basal New Oxford Formation contains facies that are similar to those of the Stockton Formation (Smoot, 1991).

Within the Newark basin, the Stockton Formation is overlain by the Upper Triassic Lockatong and Passaic Formations (fig. 5). In the central part of the basin, the Lockatong Formation mainly consists of thick beds of black shale and gray mudstone, whereas the Passaic Formation mainly consists of red mudstone and silty mudstone (Smoot, 2010). Near the basin margins, the Lockatong and Passaic Formations consist mainly of conglomeratic and sandstone units. Although these units are along the basin margin, the central basin facies dominate much of the strata that overlie the Stockton Formation. Together, the Lockatong and Passaic Formations are approximately 11,000 to 13,000 ft thick (Smoot, 2010), although they crop out across much of the eastern Newark basin (Lyttle and Epstein, 1987). Within the Gettysburg basin (fig. 6), there is no Carnian-age formation corresponding to the Lockatong Formation of the Newark basin (fig. 5), but the correlative formation to the Passaic Formation is the Gettysburg Formation, which is also mainly composed of red mudstone and silty mudstone (Low and others, 2002).

Within the Newark basin, the Passaic Formation is overlain by a series of Early Jurassic basalts and sedimentary units (fig. 5). In succession from oldest to youngest, these units are the Orange Mountain Basalt; siltstone, sandstone, and laminated limestone of the Feltville Formation; the Preakness Basalt; siltstone and sandstone of the Towaco Formation; the Hook Mountain Basalt; and dolomitic siltstone (which contains casts of gypsum, glauberite, and halite) of the Boonton Formation (Olsen, 1980). In the Gettysburg basin (fig. 6), the Gettysburg Formation is overlain by the Aspers Basalt of Weems and Olsen (1997), followed by the Bendersville Formation of Weems and Olsen (1997).

There has been no petroleum production from either the Newark or Gettysburg basins. There is a report of a minor oil show from the Gettysburg basin from the Leib No. 1 Sheppard well, which produced 2.5 barrels of oil in 1962 (Ziegler, 1983). Furthermore, the USGS's 1995 National Assessment of United States Oil and Gas Resources indicated that the Newark basin contains gray and black lacustrine shales that might be potential source rocks, but that there is little likelihood for any economic petroleum accumulations (Milici, 1995). Subsequently, the Eastern Mesozoic Rift Basins were reassessed by the USGS for continuous petroleum accumulations, which resulted in a potential of a mean total undiscovered resource of 876 billion cubic feet of gas and 4 million barrels of natural gas liquids in the South Newark Basin Continuous Gas Assessment Unit (Milici and others, 2012), a conclusion based on the observation that petroleum generation occurred within the shales identified in the 1995 assessment (Milici and others, 2012; Coleman and others, 2015).

The USGS assessment of the $\mathrm{CO}_{2}$ storage capacity of these basins is limited to one SAU per basin. The Stockton Formation SAU in the Newark basin was quantitatively assessed because there are clear storage and seal units in the Stockton Formation and the black shales of the Lockatong Formation. The New Oxford Formation SAU in the Gettysburg basin was not quantitatively assessed because a sealing unit correlative to the Lockatong Formation could not be identified within the timeframe of the assessment. 


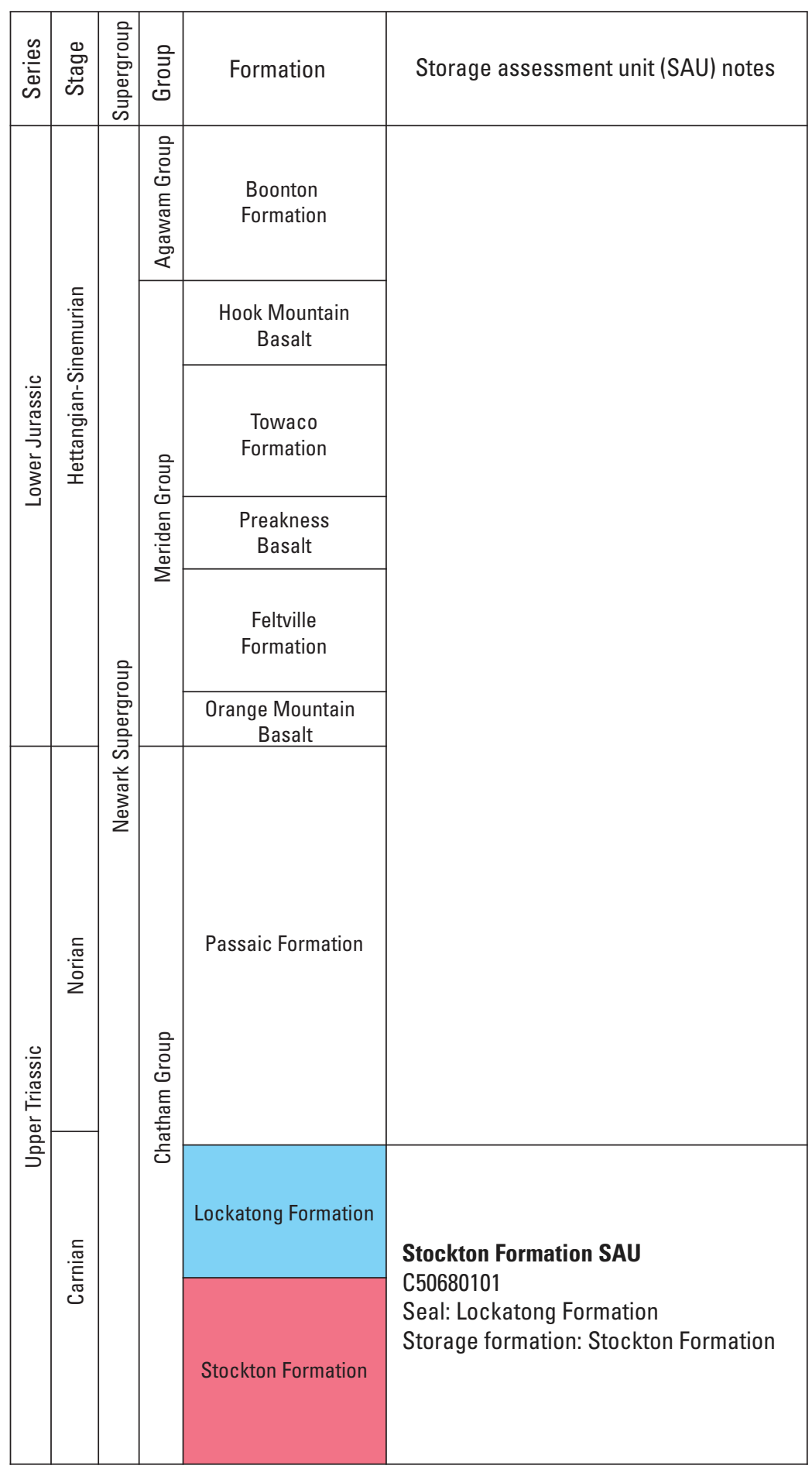

Figure 5. Stratigraphic column for the Newark basin. The Stockton Formation Storage Assessment Unit consists of a storage formation (Stockton Formation, red) and regional seal (Lockatong Formation, blue). Stratigraphic units are adapted from Weems and Olsen (1997). 


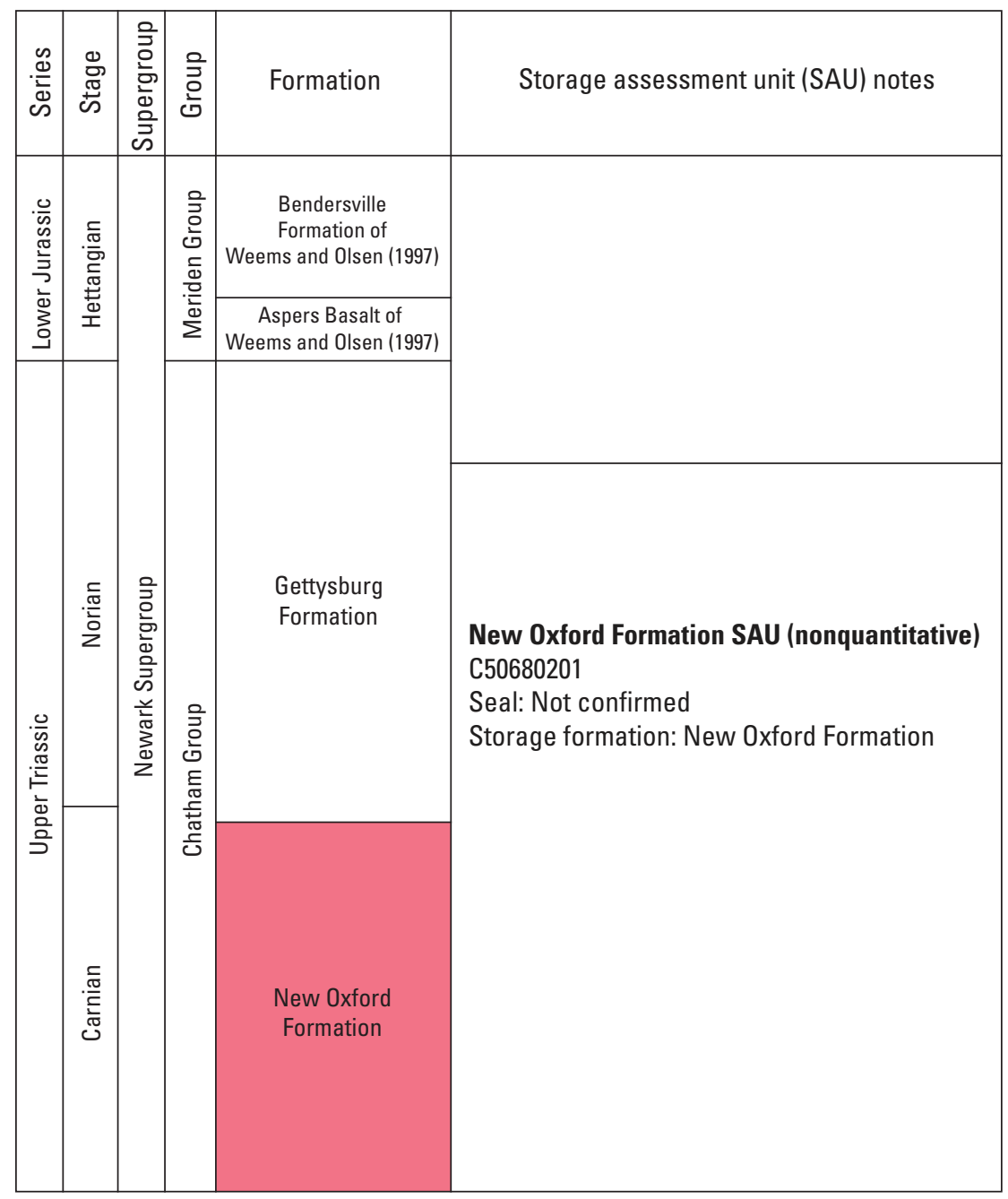

Figure 6. Stratigraphic column for the Gettysburg basin. The New Oxford Formation Storage Assessment Unit (SAU) consists of a storage formation (New Oxford Formation, red). The presence of a regional seal above this SAU could not be determined, and this SAU was not assessed quantitatively. Stratigraphic units are adapted from Weems and Olsen (1997). 


\title{
Stockton Formation SAU C50680101 and New Oxford Formation SAU C50680201
}

\author{
By Sean T. Brennan
}

The Stockton Formation SAU C50680101 (figs. 5, 7) and the New Oxford Formation SAU C50680201 (figs. 6, 8) consist of correlative Upper Triassic lacustrine strata (Olsen, 1980; Smoot, 2010) within rift basins that formed during the Mesozoic in areas that are now in the Eastern United States (Robinson and Froelich, 1985). The Stockton Formation SAU was quantitatively assessed, and the New Oxford Formation SAU was not.

The Stockton Formation SAU is within the Newark basin and is present in Pennsylvania, New Jersey, and New York (fig. 7). The Stockton Formation SAU consists of a storage formation, the siliciclastic Stockton Formation (Smoot, 2010), overlain by a sealing unit, the mudstone-rich Lockatong Formation (Smoot and Olsen, 1988; Smoot, 2010) (fig. 5).

The New Oxford Formation SAU is present within the Gettysburg basin in Pennsylvania, and a small part of the SAU extends into Maryland (fig. 8). The New Oxford Formation SAU was not quantitatively assessed for two reasons: (1) whereas a storage formation is present, there is no equivalent within the Gettysburg basin to the Lockatong Formation seal in the Newark basin (Lyttle and Epstein, 1987; Smoot, 1991) (figs. 5, 6); and (2) the lithology of the New Oxford Formation is more similar to the low-porosity siliciclastic rocks of the Manassas Sandstone than to the higher porosity beds in the Stockton Formation (Smoot, 1991). The lack of a sealing unit and the low porosity of the New Oxford Formation indicate that the New Oxford Formation SAU is not a good candidate for a quantitative assessment.

In the Stockton Formation SAU, the Stockton Formation has a maximum thickness of 5,900 ft and consists of interbedded conglomerate, arkosic sandstone, and siltstone beds (Smoot, 2010). The depositional setting of the Stockton Formation was lacustrine (Olsen, 1980; Olsen and others, 1996), although subaerial exposure features and braided fluvial deposits within the formation indicate that the water level of the lake fluctuated during deposition, and at times, the lake dried out (Smoot, 2010). The overlying Lockatong Formation is a massive mudstone (Smoot and Olsen, 1988; Smoot, 2010) that grades upward into similar lithologies in the Passaic Formation (Smoot, 2010), which is also a mudstone-rich lacustrine formation (Van Houten, 1962, 1964). The Lockatong and Passaic Formations are 11,500 to 13,000 ft thick (Smoot, 1991, 2010), and both formations crop out at the surface within the Newark basin (Olsen and others, 1996). The Lockatong Formation is sufficiently thick and consists mainly of very low permeability strata, and these characteristics make the formation a potentially effective seal unit for the Stockton Formation SAU.

The Stockton Formation SAU boundaries were defined on the basis of scant well data and interpretations by Herman (2011), who estimated the depth to the surface of the Stockton Formation and the thickness of the formation. As the thickness of the seal formation is not a factor in defining the SAU, only the depth to the top of the Stockton Formation modeled from the limited well data was used to define the boundaries of the Stockton Formation SAU (fig. 7) where the top of the formation is between 3,000 and 13,000 ft deep. The area of the SAU as defined is 997,000 acres. Because there are limited data about the Stockton Formation's rock properties within the deeper portions of the Newark basin, a deep SAU (containing strata at depths greater than 13,000 ft below the land surface) was not assessed for the Stockton Formation.

Similar methods were used to define the boundaries of the New Oxford Formation SAU (fig. 8). Because this SAU was not quantitatively assessed, it is not discussed in any more detail here.

The thickness of the Stockton Formation SAU commonly ranges between 2,000 and 4,000 ft, and the values used in this study are based on the thickness estimates of Herman (2011). Approximately half of the Stockton Formation is arkosic sandstone (Smoot, 2010), which is where most of the porous interval resides in this SAU; the sandstone fines upwards into low-porosity siltstone and mudstone seals (Olsen and others, 1996; Smoot, 2010). Therefore, the net porous interval appears to be much less than half of the total Stockton Formation thickness, which is consistent with a grain-size analysis of cores from the Newark basin (Olsen and others, 1996) and core lithology studies (Herman, 2011; Robert T. Ryder, U.S. Geological Survey, oral commun., 2012). For the Stockton Formation SAU, the net porous interval that has porosity values between 5 and 10 percent is estimated to be between 350 and $750 \mathrm{ft}$ in thickness (Herman, 2011). Because there are no reported permeability measurements from the cores in the Newark basin, analog values for fluvial-deltaic formations were used (Nelson and Kibler, 2003; Nelson, 2004). These values ranged from 0.001 to $100 \mathrm{mD}$ and had a modal value of $0.1 \mathrm{mD}$.

The regulations to protect underground sources of drinking water impose an upper limit of greater than 10,000 ppm TDS for $\mathrm{CO}_{2}$ injection projects (EPA, 2009). Because there are no reports of water chemistry for the Stockton Formation at any significant depth throughout the SAU, any estimate of the percentage of the net porous interval that contains water having greater than 10,000 ppm TDS would be uncertain. However, there are reports of anhydrite within the Stockton Formation, both as authigenic minerals and as casts filled by carbonate minerals. Magmatic activity may have occurred at the same time as the deposition of the Stockton Formation, as indicated by the presence of Jurassic igneous rocks within the Newark basin (Lyttle and Epstein, 1987; Olsen and others, 1996). Although these observations indicate that the fluids in the Stockton Formation 
may have salinities greater than 10,000 ppm TDS, there is no certainty that they do. Therefore, estimates of the amount of the Stockton Formation that would be available for storage of $\mathrm{CO}_{2}$ were chosen between 10 and 100 percent, and the modal value was 70 percent. The boundaries, thicknesses, rock properties, and water-quality information mentioned above were used in accordance with the USGS geologic $\mathrm{CO}_{2}$ storage assessment methodology (Brennan and others, 2010) to calculate the available storage space within the Stockton Formation SAU. 


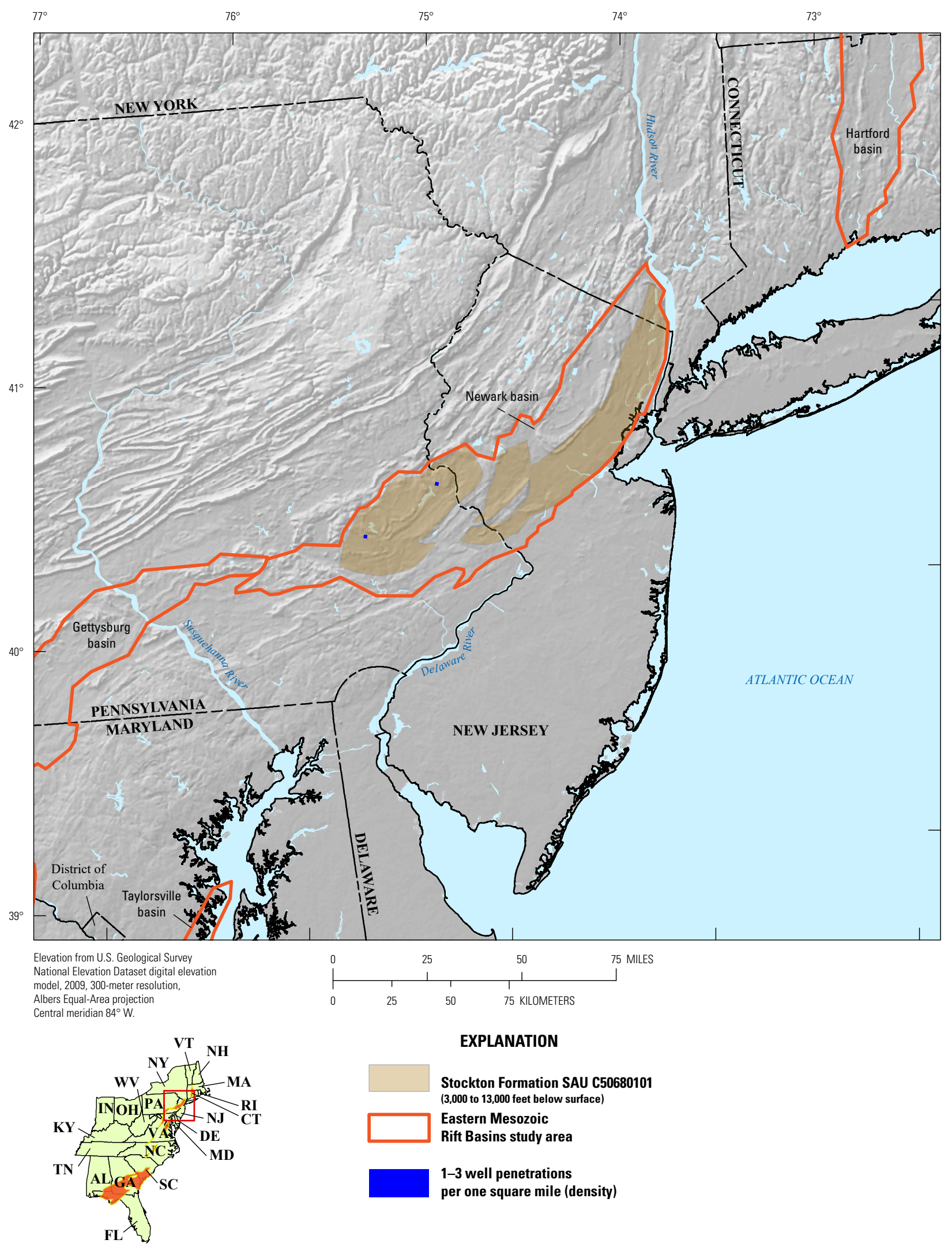

Figure 7. Map showing the area underlain by the Stockton Formation Storage Assessment Unit (SAU) in the Eastern Mesozoic Rift Basins study area. Dark-blue grid cells (1 square mile) in the SAU display counts of wells derived from the IHS Energy Group (2011) well database that have penetrated the storage formation top. The Eastern Mesozoic Rift Basins study area is modified from Coleman and Cahan (2012, fig. 2). 


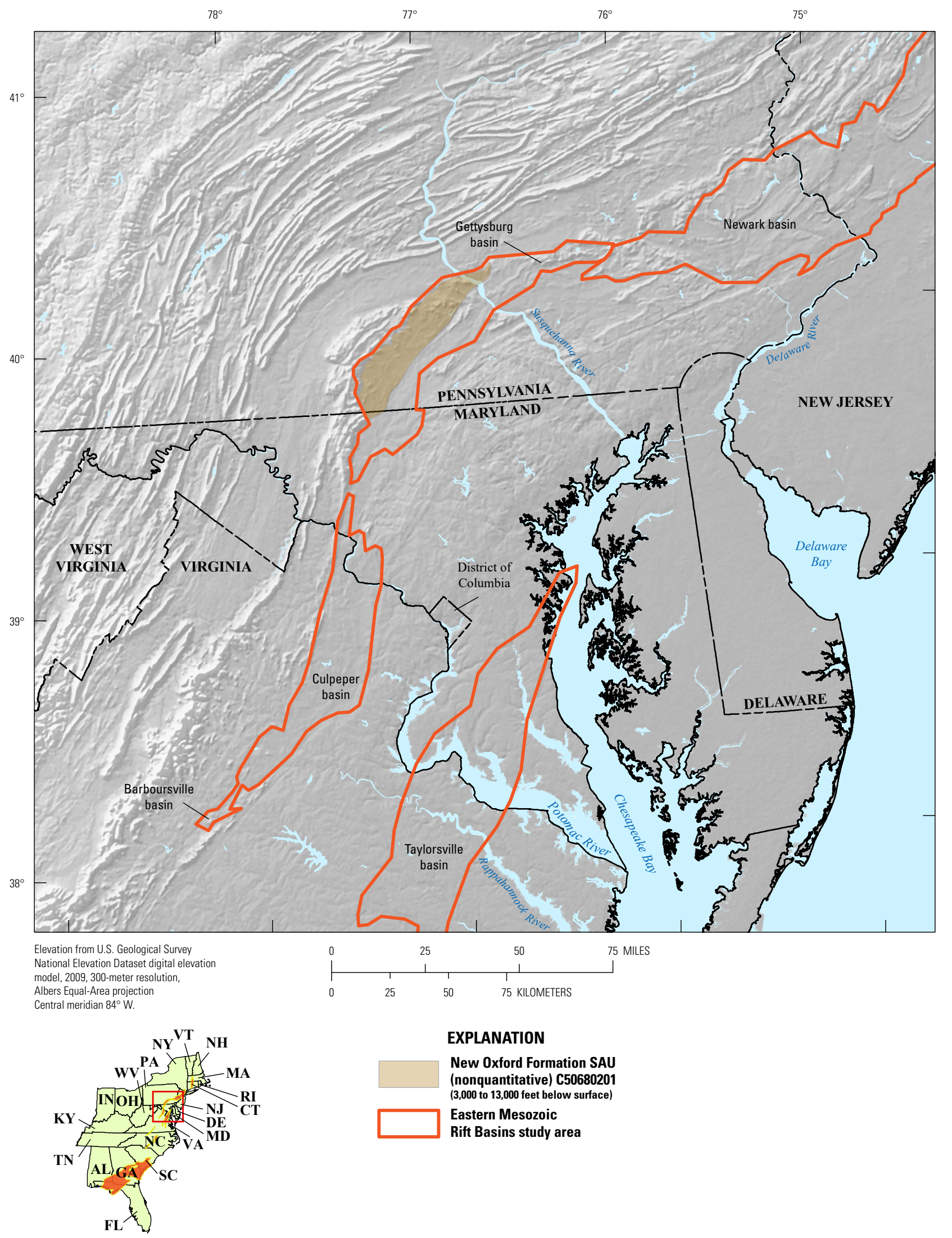

Figure 8. Map showing the area underlain by the New Oxford Formation Storage Assessment Unit (SAU) in the Eastern Mesozoic Rift Basins study area. This SAU was not assessed quantitatively. The Eastern Mesozoic Rift Basins study area is modified from Coleman and Cahan (2012, fig. 2). 


\title{
Culpeper Basin
}

\author{
By Matthew D. Merrill
}

The Culpeper Basin is a half-graben rift basin located south of the Gettysburg basin (fig. 1) and north of the Barboursville basin in the Piedmont province of eastern North America that is filled with strata of the Upper Triassic to Lower Jurassic Newark Supergroup (figs. 9, 10). Along its axis, the basin extends from just south of Frederick, Md., in the north to near Charlottesville, Va., in the south, a distance of approximately $85 \mathrm{mi}$. The western boundary of the basin is the extensional Bull Run fault (fig. 10). The eastern boundary of the basin consists of small displacement faults and unconformable contacts with basement rocks (Johnson, 1999). Strata dip west toward the Bull Run fault, and dips increase toward the west. Displacement along the Bull Run fault and associated crustal thinning produced the Culpeper basin during the Late Triassic.

Roberts (1922) was the first to study the Culpeper basin and establish its stratigraphy. Although early interpretations of the original geologic structure of the basin were incorrect, Roberts' formation names and lithologies were retained and repurposed to more accurately describe the stratigraphy (for further explanation, see Lindholm, 1979). Palynology by Cornet (1977) and successive stratigraphic studies by Lee (1977), Lindholm (1979), Lee and Froelich (1989), Smoot (1991), and Weems and Olsen (1997) have modified the established stratigraphy over time. The group-name nomenclature was established by Weems and Olsen (1997) in an effort to improve correlation of the previously known Culpeper Group (Cornet, 1977) with the existing group nomenclature of other Triassic rift basins in eastern North America. Although more proposed changes have been made to the stratigraphy of the Mesozoic rift basins of eastern North America (Weems and others, 2016), the established stratigraphy of Weems and Olsen (1997) is used in this chapter.

Sediments of the Newark Supergroup, sourced from the highlands created by faulting and later igneous activity, filled the Culpeper basin (fig. 10). Two groups are present in the basin: the Upper Triassic Chatham Group and the Lower Jurassic Meriden Group. The Chatham Group consists of (from oldest to youngest) the Manassas Sandstone, Bull Run Formation, and Catharpin Creek Formation. Lee and Froelich (1989) separated the basal Manassas Sandstone into four members. The Reston, Tuscarora Creek, and Rapidan Members are conglomerates and each is in fault contact with or unconformably overlies preTriassic crystalline rocks (Johnson, 1999). The Poolesville Member, previously the unnamed member of Lee (1977), is a fluvial sandstone and makes up the balance of the Manassas Sandstone. It is discussed below in the section titled "Manassas Sandstone SAU." The Bull Run Formation also contains four members (from oldest to youngest): the basal Balls Bluff Member (clayey and calcareous siltstone), the Groveton Member (a thick accumulation of gray and red shale and siltstone), the Leesburg Member (mostly limestone and dolomitic limestone), and the Cedar Mountain Member (greenstone conglomerate). The upper part of the Bull Run Formation interfingers with, and (or) is overlain by arkosic sandstones and conglomerates, including the Tibbstown Formation and the Catharpin Creek Formation.

The formations of the Meriden Group are of Early Jurassic age and are distinguished from the Chatham Group in the Culpeper basin because they are a mixture of sedimentary and basaltic units. The Meriden Group consists of six formations (from oldest to youngest): (1) the basal Mount Zion Church Basalt; (2) the Midland Formation, which consists of sandstone, siltstone, and shale and is 500 to $984 \mathrm{ft}$ thick (Johnson, 1999); (3) the Hickory Grove Basalt; (4) the dinosaur-footprint-bearing Turkey Run Formation, which consists of reddish sandstone, siltstone, and shale; (5) the Sander Basalt, which consists of hydrothermally altered and locally mineralized igneous rocks (Lee, 1977; Lee and Froelich, 1989); and (6) the Waterfall Formation, which is lithologically similar to the other sedimentary units in the group in that it consists of arkosic sandstone, siltstone, and shale, but it also contains conglomerates of silicate and quartzite clasts (Lindholm, 1979; Lee and Froelich, 1989).

Conventional accumulations of oil and gas have not been discovered in the Culpeper basin. There is potential for continuous gas resources in the basin (Milici, 1995; Milici and others, 2012; Coleman and others, 2015); however, the U.S. Geological Survey recently indicated that the potential is relatively low compared to other extensional basins along strike (Milici and others, 2012). Wilkes and others (1989) indicated that 29 drill holes have been drilled to depths of 100 to $1,200 \mathrm{ft}$ from the surface in the Culpeper basin. Drilling was conducted to explore for groundwater, hydrocarbons, and geothermal resources and to improve the geologic understanding of the subsurface.

The USGS assessment of $\mathrm{CO}_{2}$ storage potential in saline aquifers of the Culpeper basin is limited to one SAU: the Manassas Sandstone SAU. This SAU was not assessed quantitatively because of a probable lack of reservoir porosity and permeability at depth. The potential for nonsedimentary units such as basalts to serve as both seals and reservoirs for carbon dioxide storage is an active area of research. However, because of a lack of subsurface data and reservoir properties for the basalts of the Culpeper basin, these units were not considered as potential SAUs. 


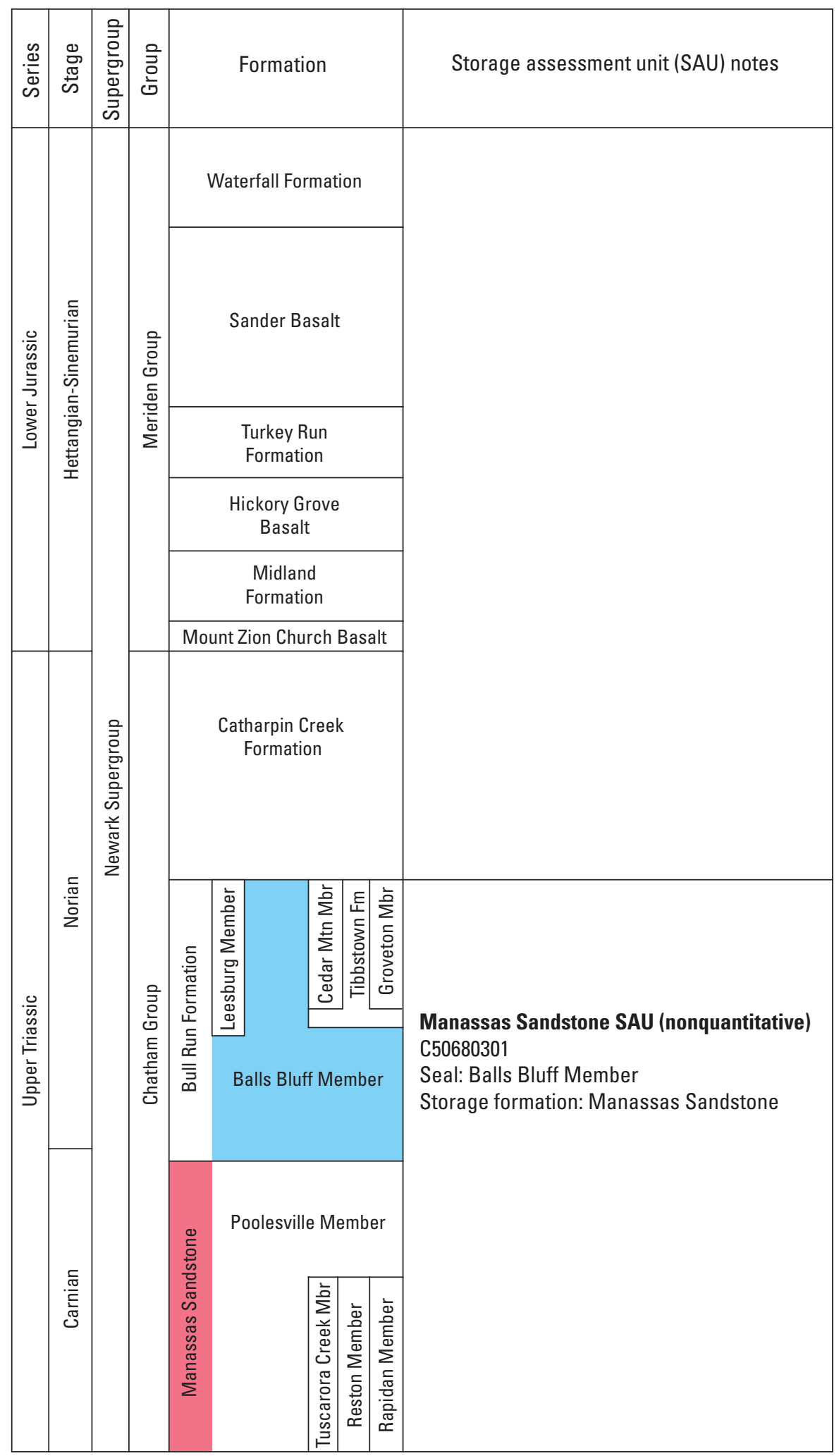

Figure 9. Stratigraphic column for the Culpeper basin. The Manassas Sandstone Storage Assessment Unit consists of a storage formation (Manassas Sandstone, red) and a regional seal (Balls Bluff Member of the Bull Run Formation, blue). Stratigraphic units are adapted from Lee and Froelich (1989), and units above the Bull Run Formation are simplified from Weems and Olsen (1997). Fm, Formation; Mbr, Member; Mtn, Mountain. 


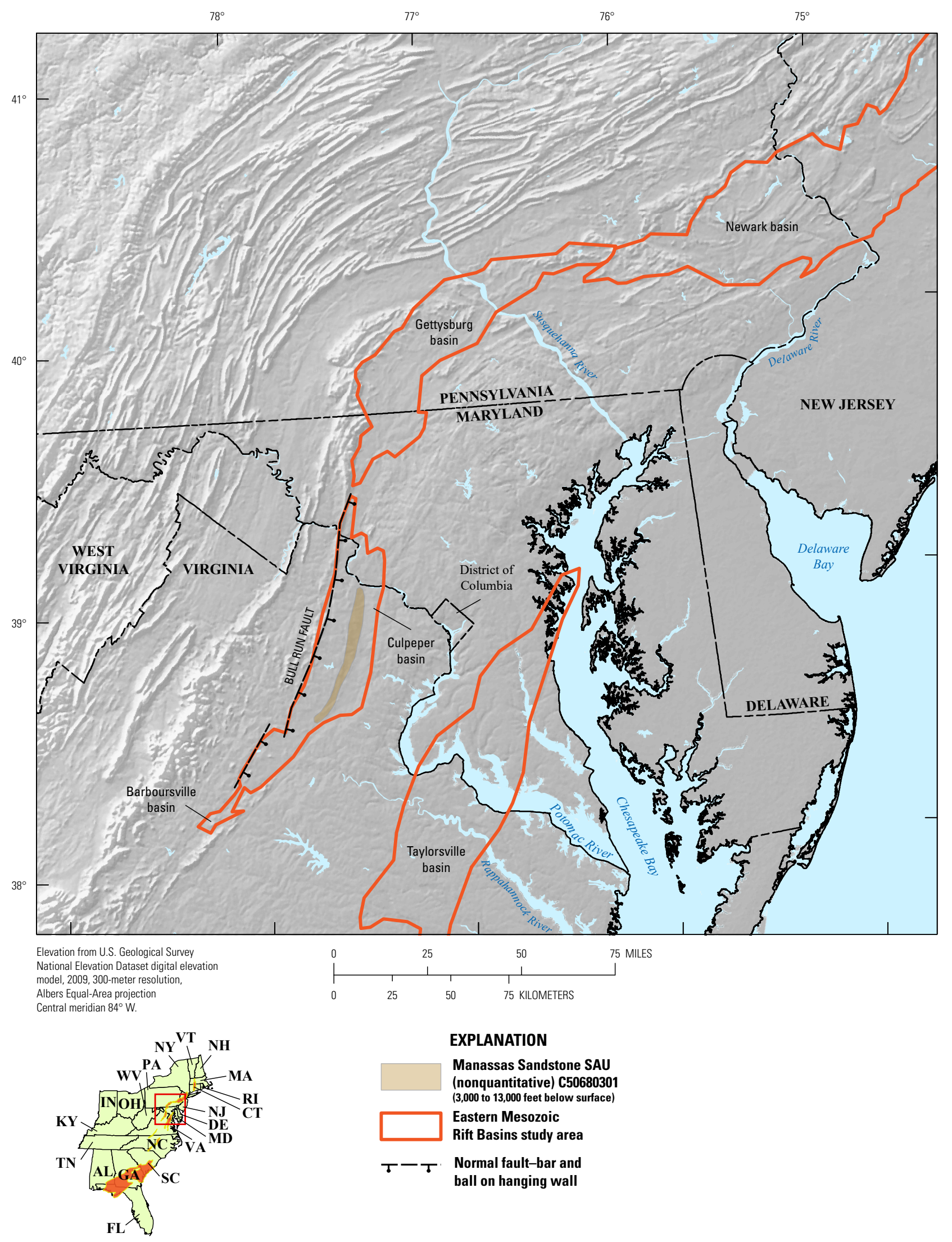

Figure 10. Map showing the Culpeper basin and the area underlain by the Manassas Sandstone Storage Assessment Unit (SAU) in the Eastern Mesozoic Rift Basins study area. This SAU was not assessed quantitatively. The Eastern Mesozoic Rift Basins study area is modified from Coleman and Cahan (2012, fig. 2). 


\title{
Manassas Sandstone SAU C50680301
}

\author{
By Matthew D. Merrill
}

The Manassas Sandstone SAU C50680301 is an Upper Triassic SAU in the Culpeper basin that consists of the Manassas Sandstone (of Carnian age) as a storage formation and the Balls Bluff Member (of Carnian to Norian age) of the Bull Run Formation as its sealing unit (figs. 9, 10). The two formations are part of the Chatham Group, which is, in turn, part of the Newark Supergroup of Late Triassic to Early Jurassic age (Weems and Olsen, 1997). Fluvial and lacustrine depositional environments interpreted to have existed in the rift-generated Culpeper basin are analogous to the environments that produced similar formations in the other Mesozoic rift basins included in this chapter (see the "Introduction"). This SAU (fig. 9) was not quantitatively assessed because of the paucity of data and the low probability of a storage formation with good reservoir quality at depth. The presence of extensional faults and diabase dikes and sills throughout the potential storage formation and seal could limit the size of the area suitable for storage because of complex compartmentalization. The boundaries for this SAU are uncertain because of a lack of well control. The approximate area where the SAU ranges in depth from 3,000 ft (at its upper contact) to 13,000 $\mathrm{ft}$ (at its lower contact) was based on surface geology maps by Lee and Froelich (1989) and a cross section constrained by seismicreflection data from Ryan and others (2006).

The stratigraphy of Weems and Olsen (1997) is used in the following discussion. The shale-dominant strata of the Balls Bluff and Groveton Members of the Bull Run Formation (previously assigned to the Balls Bluff Siltstone) are 310 to 7,000 $\mathrm{ft}$ thick (Lee, 1977). Repeated sections from faulting in the basin may explain the great thickness. The Bull Run Formation is the main sedimentary constituent of the basin and is exposed along Bull Run in Fairfax, Loudoun, and Prince William Counties, Va., as well as along the Potomac River in the northern part of the basin (Lee, 1977). Locally, the unit consists of thin beds of blackish-gray limestone; gray dolomite; and light-gray to dark-red, fine- to medium-grained sandstone (Lee, 1977). In the Newark Supergroup facies descriptions of Smoot (1991), the Balls Bluff Formation falls into the L4 to L6 lacustrine facies categories, which consist primarily of mudstone. The mudstone is locally sandy, is locally interbedded with siltstone and rippled sandstone, and exhibits a variety of structures, such as polygonal cracks, root structures, and burrows that are common in parts of the formation. The formation dips moderately to the west in the eastern and central portions of the basin and dips more steeply on the western side (Ryan and others, 2006).

According to Lee (1977), the Manassas Sandstone contains three conglomeratic members (Reston, Tuscarora Creek, and Rapidan Members) and the Poolesville Member, which is extensive in the eastern part of the basin and is exposed along Bull Run and the Potomac River. The Poolesville Member ranges from about 1,000 ft to about 3,000-5,000 ft in gross thickness and consists of feldspar and quartz grains surrounded by a red clay and silt matrix (Lee, 1977; Lee and Froelich, 1989). Smoot (1991) described the sandstones as a variety of fluvial facies in the Newark Supergroup. These range from braided- and meandering-stream deposits of medium-grained, crossbedded sandstones to stacked sequences of sandstone and mudstone that exhibit pervasive bioturbation (Smoot, 1991). The shallow water wells in the Manassas Sandstone are productive because of fracture porosity and permeability, not because of matrix porosity and permeability. At depth, cementation is similar to that in near-surface beds and the available porosity is assumed to be low (Smoot, 1991). There are no production data or deep wells in the Manassas Sandstone.

\section{Basins Not Assessed}

Many of the Eastern Mesozoic Rift Basins were reviewed and then discounted as potential sites for geologic $\mathrm{CO}_{2}$ sequestration. A brief geologic description for each of these basins is presented below, as is a summary of the rationale for not conducting assessments in these basins. Most commonly, basins were discounted for geologic $\mathrm{CO}_{2}$ storage in saline aquifers because of (1) the apparent absence of (or inability to characterize) regional sealing formations that have sufficiently large spatial extent and (or) (2) the lack of rock with acceptable reservoir quality at depths greater than 3,000 ft (see Burruss and others, 2009; Brennan and others, 2010; Blondes and others, 2013). 


\section{Hartford Basin}

\section{By Matthew D. Merrill}

The Jurassic and Triassic Hartford basin (fig. 1) and the smaller Deerfield basin are asymmetrical, east-dipping, north- to south-elongated, extensional, half-graben rift basins. When considered together, the two basins are roughly $100 \mathrm{mi}$ in length and extend south from the Massachusetts-Vermont border to Long Island Sound. The Hartford basin is bounded to the east by the Eastern Border fault, on the west by the shorter Mixville fault in Connecticut, and by other local faults in Massachusetts. Although hydrocarbon exploration and subsurface data in the basin are limited (Hubert and others, 1992), the surficial geology of the basin is well known from outcrop studies (Krynine, 1950; LeTourneau, 1985; Olsen, 1988; Olsen and others, 2005). A fluid inclusion study has shown that hydrocarbons were generated in the basin and migrated through reservoirs, but only small amounts have been retained (Pratt and Burruss, 1988). Late Triassic to Early Jurassic sedimentary and igneous rocks in the basin are assigned to formations in the Newark Supergroup. From oldest to youngest, their depositional environments and lithologies generally range from fluvial arkosic sandstones to lacustrine shales and silts, and three major basalt units were extruded during a later lacustrine phase (Smoot, 1991). In places, the arkosic sandstones of the New Haven Arkose (see Smoot, 1991 and references therein) have the potential to serve as storage reservoirs. However, the lack of an overlying homogeneous and massive shale unit and the absence of evidence for retention of petroleum within the reservoir formation indicate that there are no sealing formations that satisfy the requirements of the methodology.

\section{Richmond Basin}

\section{By Marc L. Buursink}

The Richmond basin (along with the Taylorsville basin to the north and five smaller outlying basins) is part of the eastern belt of Early Mesozoic Rift Basins in Virginia (Goodwin and others, 1985; Costain and Çoruh, 1989; Schlische 2003) (fig. 1). The Richmond basin was examined for geologic $\mathrm{CO}_{2}$ storage potential, but it did not meet the criteria for potential regional seals and storage formations detailed in the assessment methodology (Brennan and others, 2010). The Richmond and Taylorsville basins both began as a series of small-scale rift basins related to continental extension and then evolved into two regional-scale rift basins (LeTourneau, 2003). The Richmond basin is exposed at the surface; however, "Richmond basin deposits are exceptionally poorly exposed, and environmental interpretations are mostly based on geophysical surveys, and logs and rock chips from wells" (Smoot, 1991, p. 406).

Much of the fill in the Richmond basin was deposited in the Triassic. Of the 22 oil and gas or coal tests that were drilled to depths of 1,000 ft or more in the Richmond basin (Wilkes, 1988; Milici, 1995), the Cornell Oil Company's Bailey No. 1 well, which was drilled in 1981, is the deepest; it reached basement at a depth of about 7,000 ft (Wilkes, 1988). There is a general agreement on the interpretations of depositional environments (which include braided fluvial streams, deltaic clinoforms, and perennial lakes) and on the complexity of the internal basin structure (which includes post-rift contractional structures and intrusive diabase rocks) (Weems, 1980; Cornet and Olsen, 1990; LeTourneau, 2003).

No regional seal units could be confirmed in the timeframe of the assessment. The gray to black lacustrine shales within the Upper Triassic Vinita Beds (Milici, 1995) are deep enough in some parts of the basin and may exhibit sufficient shale thickness to be a regional seal, but their regional extent is currently unknown. Furthermore, the cutoff for TDS in the basin's formation waters (as specified in the methodologies by Brennan and others, 2010; Blondes and others, 2013) may be met, but if so, the areas and depths are unknown (Weems, 1980; Smoot, 1991). 


\section{Taylorsville Basin}

\section{By Marc L. Buursink}

The Taylorsville basin evolved in a structural setting similar to that of the Richmond basin (see the section above, "Richmond Basin") and extends northward from near Richmond, Va., beneath the Atlantic Coastal Plain into adjacent parts of Maryland (fig. 1). The basin is mostly buried, and the geology has been mapped in the exposed areas (Weems, 1980). Much of the fill in the Taylorsville basin is mostly Triassic. Ultimately, "much area in the Taylorsville basin beneath the Atlantic Coastal Plain remains to be tested by the drill" (Milici, 1995, p. 10). However, similar to the Richmond basin (and other basins along strike), (a) there is general consensus on the depositional settings of the basin fill (braided fluvial streams, deltaic clinoforms, and perennial lakes), and (b) the basin has been inverted since the Triassic (Weems, 1980; Cornet and Olsen, 1990; LeTourneau, 2003).

When the basin fill was examined for potential regional seals and storage formations, no likely candidates were found. The Falling Creek Member (of middle Carnian age) of the Doswell Formation appears to contain a high shale-to-silt ratio, and as much as $300 \mathrm{ft}$ of a shale-dominant lithology is visible in some wells (Milici, 1995; LeTourneau, 2003). However, on the basis of the limited available well data, it is not clear that sufficient reservoir rock is present beneath the Falling Creek Member of the Doswell Formation (LeTourneau, 2003). Furthermore, the cutoff for TDS in the basin formation waters (as specified in the methodologies of Brennan and others, 2010; Blondes and others, 2013) may be met, but if so, the areas and depths are unknown (Weems, 1980; Smoot, 1991).

\section{Deep River and Dan River-Danville Basins}

\section{By Peter D. Warwick}

Multiple exposed and buried Triassic to Jurassic rift basins occur in central and eastern North Carolina and Virginia (Olsen and others, 1989) and are part of the Eastern Mesozoic Rift Basins study area. These basins are generally elongated north to northeast and are half-grabens that have western boundary faults. They are commonly filled with conglomeratic to fine-grained fluvial and lacustrine sediments that are interbedded with and intruded by basaltic flows, dikes, and sills of the Newark Supergroup (Costain and Çoruh, 1989; Olsen and others, 1989; Smoot, 1991; Olsen, 1997; LeTourneau and Olsen, 2003a,b). The Deep River basin of central North Carolina and the Dan River-Danville basin of North Carolina and Virginia (fig. 1) were examined for their potential for geologic storage of $\mathrm{CO}_{2}$.

The Deep River basin is approximately $120 \mathrm{mi}$ long and 5 to $15 \mathrm{mi}$ wide and is divided into the Durham (north), Sanford (central), and Wadesboro (south) subbasins (Reid and Milici, 2008). Well penetrations in the Durham and Sanford subbasins indicate that the basal Pekin Formation ranges in thickness from 1,750 ft to more than 4,000 ft and is composed of interbedded conglomerate, sandstone, siltstone, and claystone (Reinemund, 1955; Bain and Brown, 1980; Reid and Milici, 2008). The Cumnock Formation ranges in thickness from $750 \mathrm{ft}$ to more than 1,700 ft and overlies the Pekin Formation in the Durham and Sanford subbasins. The Cumnock is composed of shale containing interbeds of siltstone and fine-grained sandstone, carbonaceous shale, and coal (Reinemund, 1955; Bain and Brown, 1980; Reid and Milici, 2008; North Carolina Department of Environment and Natural Resources and North Carolina Department of Commerce, 2012). The Sanford Formation overlies the Cumnock Formation and is more than 4,000 ft thick; the Sanford Formation is composed of interbedded fine-grained to conglomeratic sandstone, siltstone, and claystone (Reinemund, 1955).

The shale-rich Cumnock Formation in the Durham and Sanford subbasins could be considered as a regional seal for geologic storage of $\mathrm{CO}_{2}$ in the underlying porous sandstones of the Pekin Formation. However, cross sections (Reinemund, 1955; Costain and Çoruh, 1989) and structure-contour maps (Reinemund, 1955; North Carolina Department of Environment and Natural Resources and North Carolina Department of Commerce, 2012) show that the depth to the top of the Cumnock Formation over most of the Durham and Sanford subbasins is less than 3,000 ft. The geologic $\mathrm{CO}_{2}$ storage assessment methodology of Brennan and others (2010) and Blondes and others (2013), used by the U.S. Geological Survey Geologic Carbon Dioxide Storage Resources Assessment Team (2013a,b,c), requires that the regional seals for $\mathrm{CO}_{2}$ storage assessment units be at depths greater than 3,000 ft. For this reason, the Deep River basin was not assessed for geologic $\mathrm{CO}_{2}$ storage. More detailed investigations and mapping of the depth of the Cumnock Formation are required to determine if some local areas of the Durham and Sanford subbasins do meet the minimum 3,000-ft seal-depth requirements. 
The Dan River-Danville basin is a half-graben, bounded by faults on its western border, that is approximately $100 \mathrm{mi}$ long and 2 to $9 \mathrm{mi}$ wide and extends across the North Carolina-Virginia border (Gore and Olsen, 1989). The basin-fill sedimentary rocks are more than 5,000 ft thick in the southwestern (Dan River) part of the basin (Thayer, 1970) and more than 20,000 ft thick in the northeastern (Danville) part of the basin (Thayer and Robbins, 1994, and references therein). The lithostratigraphic nomenclature changes across the basin. The North Carolina part of the basin includes (from oldest to youngest): (1) the Pine Hall Formation, which consists of coarse- to fine-grained, fluvial and alluvial clastic rocks up to several thousand feet thick; (2) the Cow Branch Formation, which consists of about 2,000 ft of discontinuous lenses, beds, and tongues of black and darkgray claystone, shale, siltstone, and sandstone containing organic debris; and (3) the Stoneville Formation, which consists of interbedded conglomerate, sandstone, and siltstone (Reid and Milici, 2008). Equivalent but transitional units in Virginia are the basal Leakesville Formation, the Dry Fork Formation, and the overlying Cedar Forest Formation (Gore and Olsen, 1989) or only the Dry Fork Formation where the basin fill is composed of conglomeratic and fine- to coarse-grained, fluvial to lacustrine sandstones (Thayer and Robbins, 1994, and references therein). Although the Cow Branch and Dry Fork Formations contain well-developed cyclic patterns consisting of massive, light-gray and tan silty mudstones alternating with dark-gray to black, platy, pyritic shales and carbonaceous shales (coaly in places) (Thayer and others, 1970), the U.S. Geological Survey Geologic Carbon Dioxide Storage Resources Assessment Team (2013a,b,c) considered these units to be too irregular in thickness and lateral extent to serve as a regional sealing unit for geologic $\mathrm{CO}_{2}$ storage. For this reason, the Dan River-Danville Basin was not assessed for geologic $\mathrm{CO}_{2}$ storage.

\section{South Georgia Rift Basin}

\section{By Ronald M. Drake II}

The South Georgia Rift basin (fig. 1) extends from southeastern South Carolina, across southwestern Georgia, into southeastern Alabama and western Florida and is bounded on the northwest by the Piedmont and on the southeast by the Atlantic Ocean. This southeastward-dipping buried basin was formed from the faulting and subsidence along the North American Triassic rift system during the breakup of Pangea in the Mesozoic Era (Knapp and others, 2011). The basin contains Triassic sedimentary rocks and intercalated layers of Jurassic basalt flows and diabase dikes and sills that are buried by Cretaceous and Cenozoic sediments of the Atlantic Coastal Plain.

U.S. Geological Survey assessment geologists investigated the potential for $\mathrm{CO}_{2}$ sequestration within saline aquifers in the basin. According to the $\mathrm{CO}_{2}$ storage assessment methodology (Brennan and others, 2010; Blondes and others, 2013), the top of an SAU must be at least 3,000 ft below the surface and there must be a laterally continuous, competent seal overlying the storage unit. Waddell (2010) postulated that the Triassic beds in the basin are a potential reservoir and that the overlying Jurassic flood basalt ("J" basalt or "J" horizon as used by Waddell, 2010) is a seal. However, later studies showed that the "J" basalt is not as continuous as previously thought (Akintunde and others, 2011; Heffner and others, 2012). Instead, the "J" horizon was determined to be the base of the coastal plain stratigraphic succession and not continuous Jurassic flood basalt (Akintunde and others, 2013). Although the " $\mathrm{J}$ " basalt is present in the area, it has not been thoroughly correlated throughout the basin. Also, for much of the basin, the Triassic beds are not at great enough depths to meet the USGS criteria for an SAU. Therefore, because the limited strata with acceptable reservoir quality did not meet the criterion of being at a depth of at least 3,000 ft, and because the potential sealing unit was not laterally continuous, no SAUs were assessed in the South Georgia Rift basin.

\section{Acknowledgments}

The authors thank the following U.S. Geological Survey employees or contractors for their assistance in preparing this manuscript: Paul G. Schruben and Brian Varela compiled the drilling and hydrocarbon production data for the basins, and Troy A. Cook, Mahendra K. Verma, and Hossein Jahediesfanjani helped to interpret petroleum engineering data for the basins. We thank the Geological Survey of Alabama and the North Carolina Geological Survey for supplying some of the geologic information used in this review. Jim Coleman and Bob Milici provided helpful peer reviews. Clint Scott, Elizabeth Koozmin, Rachel Gidley, and Carla Brezinski also edited this manuscript for clarity. 


\section{References Cited}

Akintunde, O.M., Knapp, C.C., Knapp, J.H., and Heffner, D.M., 2013, New constraints on buried Triassic basins and regional implication for subsurface $\mathrm{CO}_{2}$ storage from the SeisData6 seismic profile across the southeast Georgia Coastal Plain: Environmental Geosciences, v. 20, no. 1, p. 17-29. [Also available at https://doi.org/10.1306/eg.10231212008.]

Akintunde, O.M., Knapp, Camelia, Knapp, J.H., Heffner, D.M., and Shafer, John, 2011, Reinterpretation of the "J" basalt reflector from seismic data reprocessing across the Coastal Plain of Southeastern Georgia-Potential implications for longterm $\mathrm{CO}_{2}$ sequestration: American Association of Petroleum Geologists Search and Discovery Article 80174, 30 p., accessed March 8, 2012, at http://www.searchanddiscovery.com/pdfz/documents/2011/80174akintunde/ndx akintunde.pdf.html.

Almy, C.C., Jr., 1987, Lithostratigraphic-seismic evaluation of hydrocarbon potential, North Carolina coastal and continental margins-Interim report, year 2: Minerals Management Service/Association of American State Geologists Report, Year 2, 1985-1987, 18 p., 7 pls. [Also available at https://files.nc.gov/ncdeq/Energy\%20Mineral\%20and\%20Land\%20Resources/ Geological\%20Survey/OFRs_Geological_Survey/NCGS_OFR_88-01_Repository.pdf.]

Applin, P.L., and Applin, E.R., 1965, The Comanche Series and associated rocks in the subsurface in central and south Florida: U.S. Geological Survey Professional Paper 447, 84 p., 11 pls. [Also available at https://pubs.er.usgs.gov/publication/pp447.]

Applin, P.L., and Applin, E.R., 1967, The Gulf Series in the subsurface in northern Florida and southern Georgia, chap. G of Shorter contributions to general geology, 1965: U.S. Geological Survey Professional Paper 524, p. G1-G33, 7 oversize pls., 1 fossil pl. [Also available at https://pubs.er.usgs.gov/publication/pp524G.]

Bain, G.L., and Brown, C.E., 1981, Evaluation of the Durham Triassic basin of North Carolina and techniques used to characterize its waste-storage potential: U.S. Geological Survey Open-File Report 80-1295, 132 p., 1 pl. [Also available at https://pubs.er.usgs.gov/publication/ofr801295.]

Barnett, R.S., 1975, Basement structure of Florida and its tectonic implications: Transactions of the Gulf Coast Association of Geological Societies, v. 25, p. 122-142. [Also available at http://archives.datapages.com/data/gcags/ data/025/025001/0122.htm.]

Berg, T.M., Edmunds, W.E., Geyer, A.R., Glover, A.D., Hoskins, D.M., MacLachlan, D.B., Root, S.I., Sevon, W.D., and Socolow, A.A., comps., 1980, Geologic map of Pennsylvania: Harrisburg, Pa., Pennsylvania Bureau of Topographic and Geologic Survey, 3 sheets, scale 1:250,000. [Also available at http://www.docs.dcnr.pa.gov/topogeo/publications/pgspub/map/ map1/index.htm.]

Blondes, M.S., Brennan, S.T., Merrill, M.D., Buursink, M.L., Warwick, P.D., Cahan, S.M., Cook, T.A., Corum, M.D., Craddock, W.H., DeVera, C.A., Drake, R.M., II., Drew, L.J., Freeman, P.A., Lohr, C.D., Olea, R.A., Roberts-Ashby, T.L., Slucher, E.R., and Varela, B.A., 2013, National assessment of geologic carbon dioxide storage resources-Methodology implementation: U.S. Geological Survey Open-File Report 2013-1055, 26 p. [Also available at https://pubs.er.usgs.gov/publication/ ofr20131055.]

Brennan, S.T., Burruss, R.C., Merrill, M.D., Freeman, P.A., and Ruppert, L.F., 2010, A probabilistic assessment methodology for the evaluation of geologic carbon dioxide storage: U.S. Geological Survey Open-File Report 2010-1127, 31 p., accessed March 22, 2011, at http://pubs.usgs.gov/of/2010/1127/.

Brown, P.M., Brown, D.L., Reid, M.S., and Lloyd, O.B., Jr., 1979, Evaluation of the geologic and hydrologic factors related to the waste-storage potential of Mesozoic aquifers in the southern part of the Atlantic Coastal Plain, South Carolina and Georgia: U.S. Geological Survey Professional Paper 1088, 37 p., 11 pls. [Also available at https://pubs.er.usgs.gov/publication/ pp1088.]

Brown, P.M., Miller, J.A., and Swain, F.M., 1972, Structural and stratigraphic framework, and spatial distribution of permeability of the Atlantic Coastal Plain, North Carolina to New York: U.S. Geological Survey Professional Paper 796, 79 p., 59 pls. [Also available at https://pubs.er.usgs.gov/publication/pp796.]

Burruss, R.C., Brennan, S.T., Freeman, P.A., Merrill, M.D., Ruppert, L.F., Becker, M.F., Herkelrath, W.N., Kharaka, Y.K., Neuzil, C.E., Swanson, S.M., Cook, T.A., Klett, T.R., Nelson, P.H., and Schenk, C.J., 2009, Development of a probabilistic assessment methodology for evaluation of carbon dioxide storage: U.S. Geological Survey Open-File Report 2009-1035, 81 p., accessed March 22, 2011, at http://pubs.usgs.gov/of/2009/1035/. 
Cleaves, E.T., Edwards, Jonathan, Jr., and Glaser, J.D., comps., 1968, Geologic map of Maryland: Baltimore, Md., Maryland Geological Survey, scale 1:250,000.

Coleman, J.L., Jr., and Cahan, S.M., 2012, Preliminary catalog of the sedimentary basins of the United States: U.S. Geological Survey Open-File Report 2012-1111, 27 p. (plus 4 figures and 1 table available as separate files), accessed 2012, at http://pubs.usgs.gov/of/2012/1111/.

Coleman, J.L., Jr., Milici, R.C., and Post, P.J., 2015, Assessment of the oil and natural gas potential of the east coast Mesozoic synrift basins, onshore and State waters of the United States, in Post, P.J., Coleman, J.L, Jr., Rosen, N.C., Brown, D.E., Roberts-Ashby, Tina, Kahn, Peter, and Rowan, Mark, eds., Petroleum systems in "rift" basins: GCSSEPM Foundation Perkins-Rosen Research Conference, 34th, Houston, Tex., December 13-16, 2015, Proceedings, p. 69-131, on DVD.

Cornet, Bruce, 1977, The palynostratigraphy and age of the Newark Supergroup: University Park, The Pennsylvania State University, unpub. Ph.D. dissertation, 505 p.

Cornet, Bruce, and Olsen, P.E., 1990, Early to middle Carnian (Triassic) flora and fauna of the Richmond and Taylorsville basins, Virginia and Maryland, U.S.A.: Virginia Museum of Natural History Guidebook 1, 83 p. [Also available at https://www.researchgate.net/publication/301677351 EARLY TO MIDDLE_CARNIAN_TRIASSIC FLORA_AND FAUNA_OF_THE_RICHMOND_AND_TAYLORSVILLE_BASINS_VIRGINIA_AND_MARYLAND_USA.]

Costain, J.K., and Çoruh, Cahit, 1989, Tectonic setting of Triassic half-grabens in the Appalachians-Seismic data acquisition, processing, and results, chap. 11 of Tankard, A.J., and Balkwill, H.R., eds., Extensional tectonics and stratigraphy of the North Atlantic margins: American Association of Petroleum Geologists Memoir 46, p. 155-174. [Also available at http://archives. datapages.com/data/specpubs/structu1/data/a156/a156/0001/0150/0155.htm.]

Daniels, D.L., Zietz, Isidore, and Popenoe, Peter, 1983, Distribution of subsurface lower Mesozoic rocks in the southeastern United States, as interpreted from regional aeromagnetic and gravity maps, chap. K of Gohn, G.S., ed., Studies related to the Charleston, South Carolina, earthquake of 1886-Tectonics and seismicity: U.S. Geological Survey Professional Paper 1313, p. K1-K24. [Also available at https://pubs.er.usgs.gov/publication/pp1313.]

Faill, R.T., 1973, Tectonic development of the Triassic Newark-Gettysburg basin in Pennsylvania: Geological Society of America Bulletin, v. 84, no. 3, p. 725-740. [Also available at https://pubs.geoscienceworld.org/gsa/gsabulletin/ article/84/3/725/201324/tectonic-development-of-the-triassic-newark.]

Goodwin, B.K., Weems, R.E., Wilkes, G.P., Froelich, A.J., and Smoot, J.P., 1985, Guidebook to the geology of the Richmond and Taylorsville basins, east-central Virginia: American Association of Petroleum Geologists, Eastern Section, 14th annual meeting, Williamsburg, Virginia, November 10-12, 1985, Fieldtrip 4, 60 p.

Gore, P.J.W., and Olsen, P.E., 1989, Geology of the Dan River-Danville Basin, in Olsen, P.E., Schlische, R.W., and Gore, P.J.W., eds., Tectonic, depositional, and paleoecological history of early Mesozoic rift basins, eastern North America - Gulf, North Carolina, USA to Parrsboro, Nova Scotia, Canada, July 20-30, 1989: American Geophysical Union Field Trip Guidebook T351, p. 35-45. [Also available at https://doi.org/10.1029/FT351.]

Heffner, D.M., Knapp, J.H., Akintunde, O.M., and Knapp, C.C., 2012, Preserved extent of Jurassic flood basalt in the South Georgia Rift-A new interpretation of the J horizon: Geology, v. 40, no. 2, p. 167-170. [Also available at https://doi.org/10.1130/G32638.1.]

Herman, G.C., 2011, Characterization of the carbon dioxide storage potential of the Stockton Formation in the Newark basin, in Final report-Preliminary characterization of $\mathrm{CO}_{2}$ sequestration potential in New Jersey and the offshore coastal region: Morgantown, W. Va., U.S. Department of Energy, National Energy Technology Laboratory, prepared by New Jersey Geological Survey under cooperative agreement DE-FC26-05NT42589, p. 64-80, accessed March 8, 2012, at http://www.mrcsp.org/ userdata/phase_ii_reports/njgs_carbon_sequestration_report_web.pdf.

Hubert, J.F., Feshbach-Meriney, P.E., and Smith, M.A., 1992, The Triassic-Jurassic Hartford rift basin, Connecticut and Massachusetts-Evolution, sandstone diagenesis, and hydrocarbon history: American Association of Petroleum Geologists Bulletin, v. 76, no. 11, p. 1710-1734. [Also available at https://doi.org/10.1306/BDFF8AB0-1718-11D7-8645000102C1865D.]

IHS Energy Group, 2011, ENERDEQ U.S. well data: Englewood, Colo., IHS Energy Group, online database available from IHS Energy Group, 15 Inverness Way East, D205, Englewood, CO 80112, U.S.A., accessed January 20, 2011, at http://energy.ihs.com/. 
Johnson, D.W., 1999, The Culpeper basin: Virginia Minerals, v. 45, no. 4, p. 29-35. [Also available at https://www.dmme. virginia.gov/commercedocs/VM\%2045_4.pdf.]

Knapp, C.C., Knapp, J.H., Heffner, David, Akintunde, Martins, and Nedorub, Olga, 2011, South Georgia Rift basin—Rift initiation and evolution (RIE) assessment through controlled source seismology: EarthScope/GeoPRISMS Science Workshop for Eastern North America, Bethlehem, Pa., October 26-29, 2011, white paper, 3 p., accessed March 8, 2012, at http://geoprisms. org/wp-content/uploads/2015/02/WP_ENAM2011_knapp-et-al.pdf.

Krynine, P.D., 1950, Petrology, stratigraphy, and origin of the Triassic sedimentary rocks of Connecticut: Connecticut Geological and Natural History Survey Bulletin 73, 239 p.

Lautier, J.C., 2009, Hydrogeologic framework and ground water conditions in the North Carolina East Central Coastal Plain: Raleigh, N.C., North Carolina Department of Environment and Natural Resources, Division of Water Resources, 45 p., 53 pls. [Also available at https://www.ncwater.org/?page=282.]

Lee, K.Y., 1977, Triassic stratigraphy in the northern part of the Culpeper basin, Virginia and Maryland, chap. C of Contributions to stratigraphy: U.S. Geological Survey Bulletin 1422, p. C1-C17, 1 pl. [Also available at https://pubs.er.usgs.gov/ publication/b1422C].

Lee, K.Y., and Froelich, A.J., 1989, Triassic-Jurassic stratigraphy of the Culpeper and Barboursville basins, Virginia and Maryland: U.S. Geological Survey Professional Paper 1472, 52 p., 1 pl. [Also available at https://pubs.er.usgs.gov/publication/ pp1472.]

LeTourneau, P.M., 1985, The sedimentology and stratigraphy of the Lower Jurassic Portland Formation, central Connecticut: Middletown, Conn., Wesleyan University, unpub. M.S. thesis, 247 p., 8 pls.

LeTourneau, P.M., 2003, Stratigraphic architecture and paleomagnetic reversal stratigraphy of the Late Triassic Taylorsville basin, Virginia and Maryland, chap. 3 of LeTourneau, P.M., and Olsen, P.E., eds., Sedimentology, stratigraphy, and paleontology, v. 2 of The great rift valleys of Pangea in eastern North America: New York, Columbia University Press, p. 12-58.

LeTourneau, P.M., and Olsen, P.E., eds., 2003a, Sedimentology, stratigraphy, and paleontology, v. 2 of The great rift valleys of Pangea in eastern North America: New York, Columbia University Press, 384 p.

LeTourneau, P.M., and Olsen, P.E., eds., 2003b, Tectonics, structure, and volcanism, v. 1 of The great rift valleys of Pangea in eastern North America: New York, Columbia University Press, 214 p.

Lindholm, R.C., 1979, Geologic history and stratigraphy of the Triassic-Jurassic Culpeper basin, Virginia: Geological Society of America Bulletin, v. 90, no. 11, p. 1702-1736. [Also available at https://doi.org/10.1130/GSAB-P2-90-1702.]

Low, D.J., Hippe, D.J., and Yannacci, Dawna, 2002, Geohydrology of southeastern Pennsylvania: U.S. Geological Survey Water-Resources Investigations Report 00-4166, 347 p. [Also available at https://pubs.er.usgs.gov/publication/wri004166.]

Luttrell, G.W., 1989, Stratigraphic nomenclature of the Newark Supergroup of eastern North America: U.S. Geological Survey Bulletin 1572, 136 p., 1 pl. [Also available at https://pubs.er.usgs.gov/publication/b1572.]

Lyttle, P.T., and Epstein, J.B., 1987, Geologic map of the Newark, 1 degree by 2 degree quadrangle, New Jersey, Pennsylvania, and New York: U.S. Geological Survey Miscellaneous Investigations Map I-1715, scale 1:250,000. [Also available at https://pubs.er.usgs.gov/publication/i1715.]

Maher, J.C., 1971, Geologic framework and petroleum potential of the Atlantic Coastal Plain and continental shelf, with a section on Stratigraphy, by J.C. Maher and E.R. Applin: U.S. Geological Survey Professional Paper 659, 96 p., 17 pls. [Also available at https://pubs.er.usgs.gov/publication/pp659.]

Manspeizer, Warren, DeBoer, Jelle, Costain, J.K., Froelich, A.J., Çoruh, Cahit, Olsen, P.E., McHone, G.J., Puffer, J.H., and Prowell, D.C., 1989, Post-Paleozoic activity, chap. 6 of Hatcher, R.D., Thomas, W.A., and Viele, G.W., eds., The Appalachian-Ouachita orogen in the United States, v. F-2 of The geology of North America: Boulder, Colo., Geological Society of America, p. 319-374. [Also available at https://doi.org/10.1130/DNAG-GNA-F2.319.]

Meisler, Harold, 1989, The occurrence and geochemistry of salty ground water in the northern Atlantic Coastal Plain, chap. D of Regional aquifer-system analysis—-Northern Atlantic Coastal Plain: U.S. Geological Survey Professional Paper 1404, p. D1-D5, 6 pls. [Also available at https://pubs.er.usgs.gov/publication/pp1404D.] 
Miall, A.D., Balkwill, H.R., and McCracken, Jock, 2008, The Atlantic margin basins of North America, chap. 14 of Miall, A.D., ed., The sedimentary basins of the United States and Canada, v. 5 of Sedimentary basins of the world: Amsterdam, The Netherlands, Elsevier, p. 473-504.

Milici, R.C., 1995, Blue Ridge thrust belt (068), Piedmont Province (069), Atlantic Coastal Plain Province (070), Adirondack Province (071), and New England Province (072), in Gautier, D.L., Dolton, G.L., Takahashi, K.I., and Varnes, K.L. eds., 1995 National assessment of United States oil and gas resources-Results, methodology, and supporting data: U.S. Geological Survey Digital Data Series DDS-30, release 2, 21 p., accessed March 8, 2012, at http://certmapper.cr.usgs.gov/data/noga95/ prov68/text/prov68.pdf.

Milici, R.C., Coleman, J.L., Rowan, E.L., Cook, T.A., Charpentier, R.R., Kirschbaum, M.A., Klett, T.R., Pollastro, R.M., and Schenk, C.J., 2012, Assessment of undiscovered oil and gas resources of the East Coast Mesozoic basins of the Piedmont, Blue Ridge Thrust Belt, Atlantic Coastal Plain and New England Provinces, 2011: U.S. Geological Survey Fact Sheet 2012-3075, 2 p. [Also available at https://pubs.er.usgs.gov/publication/fs20123075.]

Miller, K.G., Kominz, M.A., Browning, J.V., Wright, J.D., Mountain, G.S., Katz, M.E., Sugarman, P.J., Cramer, B.S., Christie-Blick, Nicholas, and Pekar, S.F., 2005, The Phanerozoic record of global sea-level change: Science, v. 310, no. 5752, p. 1293-1298. [Also available at https://doi.org/10.1126/science.1116412.]

Miller, K.G., Browning, J.V., Sugarman, P.J., Monteverde, D.H., Andreasen, D.C., Lombardi, Christopher, Thornburg, Jesse, Fan, Ying, and Kopp, R.E., 2017, Lower to Mid-Cretaceous sequence stratigraphy and characterization of $\mathrm{CO}_{2}$ storage potential in the mid-Atlantic U.S. coastal plain: Journal of Sedimentary Research, v. 87, no. 6, p. 609-629. [Also available at https://doi.org/10.2110/jsr.2017.33.]

Nehring Associates Inc., 2010, Significant oil and gas fields of the United States database: Colorado Springs, Colo., Nerhing Associates, Inc., database available from Nehring Associates, Inc., P.O. Box 1655, Colorado Springs, CO 80901, U.S.A. [Includes data current as of December 2008].

Nelson, P.H., 2004, Permeability-porosity data sets for sandstones: The Leading Edge, vol. 23, no. 11, p. 1143-1144. [Also available at https://doi.org/10.1190/1.1813360.]

Nelson, P.H., and Kibler, J.E., 2003, A catalog of porosity and permeability from core plugs in siliciclastic rocks: U.S. Geological Survey Open-File Report 2003-420, accessed March 8, 2012, at http://pubs.usgs.gov/of/2003/ofr-03-420/ofr-03-420.html.

North Carolina Department of Environment and Natural Resources, and North Carolina Department of Commerce, 2012, North Carolina oil and gas study under Session Law 2011-276: Raleigh, N.C., North Carolina Department of Environment and Natural Resources, 484 p., accessed June 2, 2016, at http://cdm16062.contentdm.oclc.org/cdm/ref/collection/p249901 coll22/ $\mathrm{id} / 505867$.

Olsen, P.E., 1980, Triassic and Jurassic formations of the Newark basin, in Manspeizer, Warren, ed., Field studies of New Jersey geology and guide to field trips - 52nd annual meeting of the New York State Geological Association: Newark, N.J., Rutgers University, Newark College of Arts and Sciences, Geology Department, p. 2-39. [Also available at http://www.nysga-online. net/download/1980s-nysga-guidebooks/.]

Olsen, P.E., 1988, Continuity of strata in the Newark and Hartford basins, in Froelich, A.J., and Robinson, G.R., Jr., eds., Studies of the early Mesozoic basins of the Eastern United States: U.S. Geological Survey Bulletin 1776, p. 6-18. [Also available at https://pubs.er.usgs.gov/publication/b1776.]

Olsen, P.E., 1997, Stratigraphic record of the early Mesozoic breakup of Pangea in the Laurasia-Gondwana rift system: Annual Review of Earth and Planetary Sciences, v. 25, p. 337-401. [Also available at https://doi.org/10.1146/annurev.earth.25.1.337.]

Olsen, P.E., Kent, D.V., Cornet, Bruce, Witte, W.K., and Schlische, R.W., 1996, High-resolution stratigraphy of the Newark rift basin (early Mesozoic, eastern North America): Geological Society of America Bulletin, v. 108, no. 1, p. 40-77. [Also available at https://doi.org/10.1130/0016-7606(1996)108<0040:HRSOTN>2.3.CO;2.]

Olsen, P.E., Schlische, R.W., and Gore, P.J.W., eds., 1989, Tectonic, depositional, and paleoecological history of early Mesozoic rift basins, eastern North America - Gulf, North Carolina, USA to Parrsboro, Nova Scotia, Canada, July 20-30, 1989: American Geophysical Union Field Trip Guidebook T351, 174 p. [Also available at https://doi.org/10.1029/FT351.] 
Olsen, P.E., Whiteside, J.H., LeTourneau, P.M., and Huber, Phillip, 2005, Jurassic cyclostratigraphy and paleontology of the Hartford basin, in New England Intercollegiate Geological Conference, $97^{\text {th }}$ annual meeting, New Haven, Conn., September 30, October 1 and 2, 2005, Guidebook for field trips in Connecticut: Connecticut Geological Natural History Survey Guidebook 8, p. A4.1-A4.51. [Edited by N.W. McHone and M.J. Peterson.]

Perry, W.J., Jr., Minard, J.P., Weed, E.G.A., Robbins, E.I., and Rhodehamel, E.C., 1975, Stratigraphy of Atlantic coastal margin of United States north of Cape Hatteras-Brief survey: American Association of Petroleum Geologists Bulletin, v. 59, no. 9, p. 1529-1548. [Also available at http://archives.datapages.com/data/bulletns/1974-76/data/pg/0059/0009/1500/1529.htm.]

Poag, C.W., 1978, Stratigraphy of the Atlantic continental shelf and slope of the United States: Annual Reviews of Earth and Planetary Science, v. 6, p. 251-280. [Also available at https://doi.org/10.1146/annurev.ea.06.050178.001343.]

Poag, C.W., ed., 1985, Geologic evolution of the United States Atlantic margin: New York, Van Nostrand Reinhold, 383 p.

Pratt, L.M., and Burruss, R.C., 1988, Evidence for petroleum generation and migration in the Hartford and Newark basins, in Froelich, A.J., and Robinson, G.R., Jr., eds., Studies of the early Mesozoic basins of the Eastern United States: U.S. Geological Survey Bulletin 1776, p. 74-78. [Also available at https://pubs.er.usgs.gov/publication/b1776.]

Reid, J.C., and Milici, R.C., 2008, Hydrocarbon source rocks in the Deep River and Dan River Triassic basins, North Carolina: U.S. Geological Survey Open-File Report 2008-1108, 27 p. [Also available at https://pubs.er.usgs.gov/publication/ ofr20081108.]

Reid, J.C., DePoy, Elizabeth, and Taylor, K.B., 2011, Preliminary carbon dioxide $\left(\mathrm{CO}_{2}\right)$ sequestration characterization, Dare, Tyrrell, and Hyde Counties, North Carolina: North Carolina Geological Survey Open-File Report 2011-12, 39 p.

Reinemund, J.A., 1955, Geology of the Deep River coal field, North Carolina: U.S. Geological Survey Professional Paper 246, 159 p., 8 pls. [Also available at https://pubs.er.usgs.gov/publication/pp246.]

Renken, R.A., 1996, Hydrogeology of the Southeastern Coastal Plain aquifer system in Mississippi, Alabama, Georgia, and South Carolina, chap. B of U.S. Geological Survey, Regional aquifer-system analysis - Southeastern Coastal Plain: U.S. Geological Survey Professional Paper 1410, p. B1-B101, 42 pls. [Also available at https://pubs.er.usgs.gov/publication/pp1410B.]

Richards, H.G., 1945, Subsurface stratigraphy of Atlantic Coastal Plain between New Jersey and Georgia: American Association of Petroleum Geologists Bulletin, v. 29, no. 7, p. 885-955. [Also available at http://archives.datapages.com/data/ bulletns/1944-48/data/pg/0029/0007/0850/0885.htm.]

Richards, H.G., 1967, Stratigraphy of Atlantic Coastal Plain between Long Island and Georgia-Review: American Association of Petroleum Geologists Bulletin, v. 51, no. 12, p. 2400-2429. [Also available at http://archives.datapages.com/data/ bulletns/1965-67/data/pg/0051/0012/2400/2400.htm.]

Roberts, J.K., 1922, The Triassic of northern Virginia: Baltimore, Md., Johns Hopkins University, unpub. Ph.D dissertation, $272 \mathrm{p}$.

Robinson, G.R., Jr., and Froelich, A.J., eds., 1985, Proceedings of the second U.S. Geological Survey workshop on the early Mesozoic basins of the Eastern United States: U.S. Geological Survey Circular 946, 147 p. [Also available at https://pubs. er.usgs.gov/publication/cir946.]

Root, S.I., 1989, Basement control of structure in the Gettysburg rift basin, Pennsylvania and Maryland: Tectonophysics, v. 166, no. 4, p. 281-292. [Also available at https://doi.org/10.1016/0040-1951(89)90281-3.]

Ryan, M.P., Pierce, H.A., Johnson, C.D., Sutphin, D.M., Daniels, D.L., Smoot, J.P., Costain, J.K., Çoruh, Cahit, and Harlow, G.E., 2007, Reconnaissance borehole geophysical, geological, and hydrological data from the proposed hydrodynamic compartments of the Culpeper basin in Loudoun, Prince William, Culpeper, Orange, and Fairfax Counties, Virginia (ver. 1.0): U.S. Geological Survey Open File Report 2006-1203, 43 p. [Also available at https://pubs.usgs.gov/of/2006/1203/.]

Schlische, R.W., 2003, Progress in understanding the structural geology, basin evolution, and tectonic history of the eastern North American rift system, chap. 4 of LeTourneau, P.M., and Olsen, P.E., eds., Tectonics, structure, and volcanism, v. 1 of The great rift valleys of Pangea in eastern North America: New York, Columbia University Press, p. 21-64. 
Schlische, R.W., and Olsen, P.E., 1990, Quantitative filling model for continental extensional basins with applications to early Mesozoic rifts of eastern North America: The Journal of Geology, v. 98, no. 2, p. 135-155. [Also available at https://doi. org/10.1086/629390.]

Sheridan, R.E., and Grow, J.A., eds., 1988, The Atlantic continental margin-U.S., v. I-2 of The geology of North America: Boulder, Colo., Geological Society of America, 610 p. [Also available at https://doi.org/10.1130/DNAG-GNA-I2.]

Smoot, J.P., 1991, Sedimentary facies and depositional environments of early Mesozoic Newark Supergroup basins, eastern North America: Paleogeography, Paleoclimatology, Paleoecology, v. 84, nos. 1-4, p. 369-423. [Also available at https://doi.org/10.1016/0031-0182(91)90055-V.]

Smoot, J.P., 2010, Triassic depositional facies in the Newark basin, chap. A of Hermann, G.C., and Serfes, M.E., eds., Contributions to the geology and hydrogeology of the Newark basin: New Jersey Geological Survey Bulletin 77, p. A1-A110. [Also available at http://www.state.nj.us/dep/njgs/enviroed/oldpubs/bulletin77.pdf.]

Smoot, J.P., and Olsen, P.E., 1988, Massive mudstones in basin analysis and paleoclimatic interpretation of the Newark Supergroup, chap. 10 of Manspeizer, Warren, ed., Triassic-Jurassic rifting - continental breakup and the origin of the Atlantic Ocean and passive margins: Amsterdam, The Netherlands, Elsevier, p. 249-274.

Spangler, W.B., 1950, Subsurface geology of Atlantic Coastal Plain of North Carolina: American Association of Petroleum Geologists Bulletin: v. 34, no. 1, p. 100-132. [Also available at http://archives.datapages.com/data/bulletns/1949-52/images/ pg/00340001/0100/01000.pdf.]

Temples, T.J., and Waddell, M.G., 1996, Application of petroleum geophysical well logging and sampling techniques for evaluating aquifer characteristics: Groundwater, v. 34, no. 3, p. 523-531. [Also available at https://doi. org/10.1111/j.1745-6584.1996.tb02034.x.]

Thayer, P.A., 1970, Stratigraphy and geology of Dan River Triassic basin, North Carolina: Southeastern Geology, v. 12, no. 1, p. 1-31.

Thayer, P.A., and Robbins, E.I., 1994, Late Triassic rift valley lacustrine sequence in the Dan River (North Carolina)-Danville (Virginia) basin, USA, in v. 1 of Gierlowski-Kordesch, Elizabeth, and Kelts, Kerry, eds., Global geological record of lake basins: Cambridge, United Kingdom, Cambridge University Press, p. 165-172.

Thayer, P.A., Kirstein, D.S., and Ingram, R.L., 1970, Stratigraphy, sedimentology, and economic geology of Dan River Basin, North Carolina: Raleigh, N.C., Carolina Geological Society, 44 p.

U.S. Environmental Protection Agency [EPA], 2009, Safe Drinking Water Act (SDWA): Washington, D.C., U.S. Environmental Protection Agency web site, accessed January 14, 2009, at http://www.epa.gov/ogwdw/sdwa/index.html.

U.S. Environmental Protection Agency [EPA], 2010, Final rule for Federal requirements under the underground injection control (UIC) program for carbon dioxide $\left(\mathrm{CO}_{2}\right)$ geologic sequestration (GS) wells: Washington, D.C., U.S. Environmental Protection Agency web site, accessed October 15, 2012, at http://water.epa.gov/type/groundwater/uic/class6/gsregulations.cfm.

U.S. Geological Survey Geologic Carbon Dioxide Storage Resources Assessment Team, 2013a, National assessment of geologic carbon dioxide storage resources-Summary (ver. 1.1, September 2013): U.S. Geological Survey Fact Sheet 2013-3020, 6 p., accessed December 1, 2013, at http://pubs.usgs.gov/fs/2013/3020/. [Supersedes ver. 1.0 released June 26, 2013.]

U.S. Geological Survey Geologic Carbon Dioxide Storage Resources Assessment Team, 2013b, National assessment of geologic carbon dioxide storage resources_Data (ver. 1.1, September 2013): U.S. Geological Survey Data Series 774, 13 p., plus 2 appendixes and 2 large tables in separate files, accessed December 1, 2013, at http://pubs.usgs.gov/ds/774. [Supersedes ver. 1.0 released June 26, 2013.]

U.S. Geological Survey Geologic Carbon Dioxide Storage Resources Assessment Team, 2013c, National Assessment of Geologic Carbon Dioxide Storage Resources—Results (ver. 1.1, September 2013): U.S. Geological Survey Circular 1386, 41 p., accessed December 1, 2013, at http://pubs.usgs.gov/circ/1386/. [Supersedes ver. 1.0 released June 26, 2013.]

Van Houten, F.B., 1962, Cyclic sedimentation and the origin of analcime-rich Upper Triassic Lockatong Formation, west-central New Jersey and adjacent Pennsylvania: American Journal of Science, v. 260, p. 561-576. [Also available at https:/doi. org/10.2475/ajs.260.8.561.] 
Van Houten, F.B., 1964, Cyclic lacustrine sedimentation, Upper Triassic Lockatong Formation, central New Jersey and adjacent Pennsylvania, in Merriam, D.F., ed., Symposium on cyclic sedimentation: Kansas Geological Survey Bulletin 169, p. 497-531. [Also available at http://www.kgs.ku.edu/Publications/Bulletins/169/VanHouten/index.html.]

Waddell, M.G., 2010, Geologic characterization of the South Georgia Rift basin for source proximal $\mathrm{CO}_{2}$ storage: U.S. Department of Energy, National Energy Technology Laboratory, Regional Carbon Sequestration Partnerships Annual Review Meeting, Pittsburgh, Pa., October 5-7, 2010, presentation, 30 slides, accessed March 8, 2012, at http://www.netl.doe.gov/ publications/proceedings/10/rcsp/presentations/Thur\%20am/Brian\%20Dressel/Waddell.2010\%20South\%20Carolina\%20 Partnerships\%20Meeting\%20Presentatio.pdf.

Weems, R.E., 1980, Geology of the Taylorsville basin, Hanover County, Virginia, in Virginia Division of Mineral Resources, Contributions to Virginia geology-IV: Virginia Division of Mineral Resources Publication 27, p. 23-38. [Also available at https://www.dmme.virginia.gov/commercedocs/PUB_27.pdf.]

Weems, R.E., and Olsen, P.E., 1997, Synthesis and revision of groups within the Newark Supergroup, eastern North America: Geological Society of America Bulletin, v. 109, no. 2, p. 195-209. [Also available at https://doi.org/10.1130/00167606(1997)109<0195:SAROGW>2.3.CO;2.]

Weems, R.E., Tanner, L.H., and Lucas, S.G., 2016, Synthesis and revision of the lithostratigraphic groups and formations in the Upper Permian? - Lower Jurassic Newark Supergroup of eastern North America: Stratigraphy, v. 13, no. 2, p. 111-153. [Also available at http://www.micropress.org/microaccess/stratigraphy/issue-326/article-1988.]

Wilkes, G.P., 1988, Mining history of the Richmond coalfield of Virginia: Virginia Division of Mineral Resources Publication 85, 51 p., 1 pl. [Also available at https://www.dmme.virginia.gov/commercedocs/PUB_85.pdf.]

Wilkes, G.P., Johnson, S.S., and Milici, R.C., 1989, Exposed and inferred early Mesozoic basins onshore and offshore, Virginia: Virginia Division of Mineral Resources Publication 94, 2 sheets, scale 1:500,000. [Also available at https://www.dmme. virginia.gov/commercedocs/PUB_94.pdf.]

Winner, M.D., Jr., and Coble, R.W., 1996, Hydrogeologic framework of the North Carolina coastal plain, chap. I of Regional aquifer-system analysis-Northern Atlantic Coastal Plain: U.S. Geological Survey Professional Paper 1401, p. I1-I106, 24 pls. [Also available at https://pubs.er.usgs.gov/publication/pp1404I.]

Ziegler, D.G., 1983, Hydrocarbon potential of the Newark rift system—Eastern North America: Northeastern Geology, v. 5, nos. 3-4, p. 200-208. 